Portland State University

PDXScholar

8-21-1972

\title{
Black Studies as an Agent of Social Change on the Structural Level at Selected Colleges and Universities
}

Vincent Van Davis

Portland State University

Follow this and additional works at: https://pdxscholar.library.pdx.edu/open_access_etds

Part of the Higher Education Commons, and the Race and Ethnicity Commons

Let us know how access to this document benefits you.

\section{Recommended Citation}

Davis, Vincent Van, "Black Studies as an Agent of Social Change on the Structural Level at Selected Colleges and Universities" (1972). Dissertations and Theses. Paper 1598.

https://doi.org/10.15760/etd.1594

This Thesis is brought to you for free and open access. It has been accepted for inclusion in Dissertations and Theses by an authorized administrator of PDXScholar. Please contact us if we can make this document more accessible: pdxscholar@pdx.edu. 
AN ABSTRACT OF THE THESIS OF Vincent Van Davis for the Master of Arts in Sociology presented August 21, 1972.

Title: Black Studies as an Agent of Social Change on the Structural Level at Selected Colleges and Universities.

APPROVED BY MEMBERS OF THE THESIS COMMITTEE:

Leonard D Cain, Chairman

C. Wilson Record

$$
\text { Ray C/Rist }
$$

In a relatively short period of time American higher education has witnessed the development of numerous black studies programs and departments. These new academic endeavors have been instrumental in producing structural changes in the institutions of higher education. Recently higher education has attempted to assess the progress of black studies programs and departments within their structures. This has been done with some attempt to assess the past of black studies as well as project the future of black studies within higher education.

Due to the hurried developmental process of black studies programs, which led to the establishment of biack studies on campuses which were 
not prepared for such an innovation, several problems have arisen.

The purposes of this thesis are (1) to study the precipitating events which led to a change in the academic structure of higher education (black studies); (2) to examine the developmental process of black studies; (3) to make some predictions about the future of black studies in higher education.

The case study method was used to examine four contrasting types of educational institutions in the state of Oregon: Reed College, Linfield College, Portland State University, and the University of Oregon. Two are sma11, two rather large; two are in a large metropolitan area, two in smaller cities; two are public, two are private.

The findings indicate that although stages in the developmental process were similar on the campuses, local conditions are important in explaining the distinctive types of black studies programs on each campus. 
BLACK STUDIES AS AN AGENT OF SOCIAL CHANGE ON THE STRUCTURAL LEVEL AT SELECTED COLLLEGES AND UNIVERSITIES

\author{
by
}

VINCENT VAN DAVIS

A thesis submitted in partial fulfillment of the requirements for the degree of

\author{
MASTER OF ARTS \\ in \\ SOCIOLOGY
}

Portland State University

1972 
TO THE OFFICE OF GRADUATE STUDIES AND RESEARCH:

The members of the Committee approve the thesis of Vincent Van Davis presented August 21, 1972.

Leoriard D Cain, Chäirman

C. WiTson Record

$c$

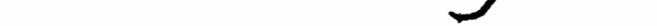

Ray C: Rist

APPROVED:

Don C. Gibbons, Head, Department of Sociology

7

Davld T. Ciark, Dean of Graduate Studies 


\section{ACKNDW TOGMENTS}

I would like to take this opportunity to express my sincere thanks to the members of my thesis committee--Leonard Cain, Wilson Record and Ray Rist--for their help and guidance. Especially I would thank Dr. Cain for his theoretical persistence, criticisms, patience and encouragement in directing this thesis to its conclusion.

Also, many thanks go to Rosiyn MacDonald, secretary par excellence, for her time, patience and expertise which have transformed this thesis from shambles into a work that others might also read. 


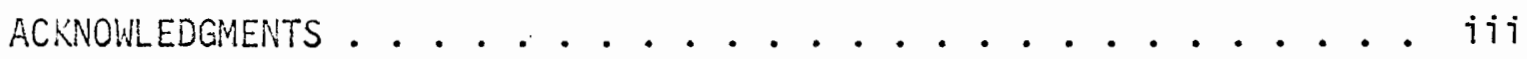
LIST OF FIGURES ......................... iv CHAPTER

I INTRODUCTION. ......................... 1

Statement of the Problem. . . ....... 4

II REVIEW OF THE LITERATURE ON BLACK STUDIES . . . . . . 7

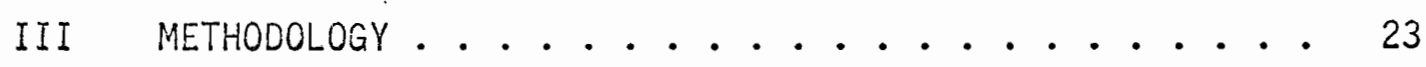

Source of Data. . . . . . . . . . 24 Respondents

Measurement Instrument. . . . . . . . 24 24

Primary Data

Secondary Data

Procedure ............. 2. 25

IV GENERAL BACKGROUND INFORMATION ON FOUR SELECTED EDUCATIONAL INSTITUTIONS: REED COLLEGE, LINFIELD COLLEGE, PORTLAND STATE UNIVERSITY, UNIVERSITY OF

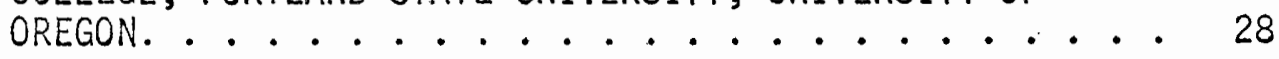

Reed College............... 28

ReTevant Student Organizations

Academic Structure of the Institution

Location of the College

Current Status of Black Studies

Linfield College. . . . . . . . . .

Relevant Student Organizations

Academic Structure of the Institution

Location of the College

Current Status of BIack Studies 
Portland State University . . . . . . . . 30

Relevant Student Organizations

Academic Structure of the Institution

Location of the University

Current Status of Black Studies

The University of Oregon. . . . . . . . .

Relevant Student Organizations

Academic Structure of the Institution

Location of the University

Current Status of Black Studies

$\checkmark$ CASE STUDIES OF FOUR SELECTED EDUCATIONAL INSTITUTIONS:

REED COLLEGE, LINFIELD COLLEGE, PORTLAND STATE UNIVER-

SITY, UNIVERSITY OF OREGON. . . . . . . . . . 33

Reed College............. 33

Linfield College............. 45

Portland State University ......... 50

The University of Oregon.......... 61

VI ANALYSIS OF THE DATA FROM THE FOUR CASE STUDIES AND

GENERAL INTERFRETATION. ............ 71

Reed College: Analysis.......... 71

Academic Structure of the Institution

Location of the Campus

Current Status of BTack Studies

Linfield College. . . . . . . . . 76

Portiand State University: Anaiysis. . . . . . 77

Academic Structure of the Institution

Location of the Campus

Current Status of Black Studies

The University of Oregon. . . . . . . . .

Academic Structure of the Institution

Location of the Campus

Current Status of Ethnic Studies 
The Role of Black Studies in Redesigning Academic Structures. . . . . . . . 83

The Role of Faculty Counselors ........ 85

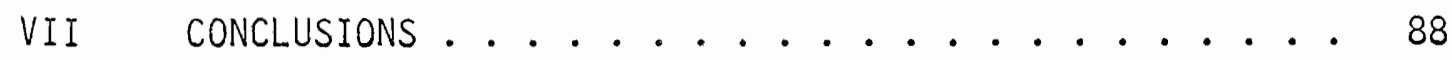

REFERENCES. . . . . . . . . . . . . . . . . . 94

BIBLIOGRAPHY. . . . . . . . . . . . . . . . . 98

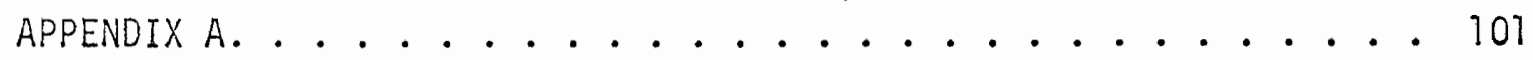

Questionnaire

APPENDIX B......................... 105

Excerpts from Tape Recordings

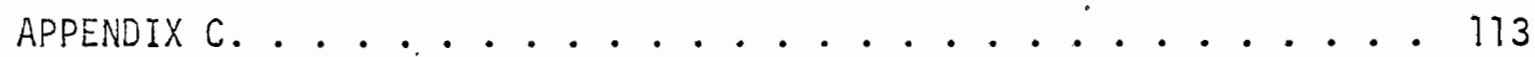

Proposed Ethnic Studies Courses at University of Oregon 


\section{LIST OF FIGURES}

FIGURES

PAGE

1 Type of Structural Change at Reed College. . . . . . 75

2 Type of Structural Change at Portland State

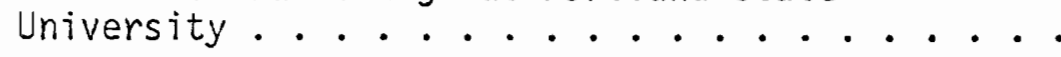


CHAPTER I

INTRODUCTION

The promotion of black studies courses in institutions of higher education has affected both those colleges which have adopted one form or another of black studies, and those which aspire to introduce black sțudies.

For those institutions that have already adopted black studies, a current task is to evaluate the success of the program. Stated differertiy by educators, "We have a black studies program (or department), but specifically, what do we have?" This question remains to be answered by many institutions. This task is proving to be difficult, primarily because of the distinctive developmental processes which led to the hasty adoption of black studies.

There is a second group of educational institutions in higher education which, for a variety of reasons, have not yet yielded to the national pressures of the black studies movement of the late 1960's. Two major reasons are: (1) location: Some colleges and universities are located in areas in which the black population is small, and few, if any, black students are in attendance at the institution; (2) the institution's structure: Many private colleges have academic standards that are exceptionally high, coupled with tuition costs that only affluent families can afford. While this doesn't stop black students from entering these institutions, it does severely limit the number of blacks who will be able to meet the standards for entrance into these institutions. 
Many in this second group of schools find black studies attractive for a variety of reasons, which will subsequently be explained. Unlike the first group of institutions which have black studies, and their accompanying problems, the second group of institutions is seeking to avoid the problems brought about in the developmental process. This is accomplished by examining the programs already in operation and by building the new programs upon the patterns of the more successful programs. There is a variety of situations and changes in the educational climate that have made black studies an attractive and feasible proposition for some educational institutions: (1) Many concerned white students have been made aware of the gaps of knowledge of the black American by the black movement and influential publications that are appearing in higher education, e.g., The Autobiography of Malcolm $X^{7}$ and Cleaver's Soul on Ice; $^{2}$ (2) It is now possible to examine several selected programs, in a non-pressured, objective and analytical manner, and thus to choose desired qualities in an attempt to minimize the risk of potential problems; (3) For some colleges it is financially advantageous to attract and retain black studerits on their campus. This is partly because of Federal monies that might be forthcoming, as well as grants from private sources; and (4) Civil Rights legislation, which affects public institutions especially, may carry financial consequences if curricular innovations regarding minorities are delayed.

Although black studies needs to be analyzed within the context of social conditions and historical trends during its germination, the many themes and currents that run through the developmental process of black studies suggest that we need to begin with a broad theoretical context. 
Black educators and students who were involved in the developmental process of black studies were attempting to introduce a total system of social, cultural, and intellectual meaning. The system was referred to as the Black Experience, which subsequently served as the ordering principle for much of the course content of black studies in higher education. This was the basic platform bargained for, although there were other demands introduced, along with a rationale as to why they should be implemented.

The position of higher education, as represented by faculty and staff, initially involved an element of caution. This is in spite of the fact that in many cases the faculty and staff of various institutions had made favorable overtures in the direction of black studies. This caution can be attributed to many variables and issues: (1) the issue of power, of who will have control of the program; (2) the variable of personal and vested interests; (3) structural changes affecting academic status; and (4) re-allocation of finances. But for a large part of the faculty and staff, apprehension was based on a knowledge gap regarding the social and cultural context of the Black Experience. Stated different7y, white educators were uncertain as to what would be disseminated as knowledge in higher education. Secondly, there was no adequate curricular criterion to evaluate such an experience.

The process by which the synthesis was to occur is a major theme in the developmental process of black studies; this theme is conflict. 
Statement of Interest and Problem

In the Fall of 1968 the author had just transferred from a junior college of approximately 6,000 students to attend San Francisco State College, a campus of approximately 18,000 students. Upon transferring to San Francisco State, as part of a personal reorientation, the author began to note significant persons, interest groups, and events on campus. However, what unfolded was a series of events that led to a general strike on November 6, 1968, followed by confrontations between the students and the police; classes in some cases were moved off campus for the safety of the students; there was a teachers' strike and finally what appeared to be the generai collapse of "normal" campus life.

During the crisis, students, instructors, and some administrators found themselves reacting, in large part, to the uniqueness of the events that unfolded. In some particular cases students and faculty were reacting to the pressures that the events generated, i.e., specific demands for change. Hence only in retrospect did it become clear that certain events that appeared to be isolated, at the time, were actually part of a major theme. It also became clear that it was possible for the author as well as others to identify several key events which could be pieced together in a reasonably coherent fashion to examine: (1) the precipitating events that led to the developmental process of black studies, and (2) the developmental process itself and its outcome.

The literature to date has focused on what is considered to be the primary problem facing black studies, which is its present developmental state. As a result of this, there appear to be no detailed accounts of the specific events that have contributed to the development of black 
stucies. What does emerge, however, is what authors see as the crucial everts leading to the development of black studies in general. For exariple, Vincent Harding (1970) states that there are two critical events: (1) the assassination of Martin Luther King, Jr., and (2) influences of activities in the black community by community-conscious blacks, specirically the high risk student. ${ }^{3}$ At the secondary level of education, G. NEacher (1968) sees the critical event as an exercise in student power. He notes that students boycotted Proviso East High School in Maywood, Illinois, to gain their demands, which.included a review of the current curriculum for its content and treatment of the Black Experience in America. Shortly thereafter, McEacher noted, nine hundred students picketed the Philadelphia School Board in November, 1967, to win similar concessions, thus setting a pattern for the emergence of student power. 4 An objective of this study is to devote systematic attention to those events necessary to bring colleges and universities to the developmental process of black studies.

Another objective is to examine the developmental process of black studies on four campuses. It can be noted that, given a set of similar pressures, strikingly different programs emerge. This is believed by the author to be due, in part, to conditions and events that occur inside as well as outside the educational institution.

During the developmental years of black studies (1965-1970) many institutions were involved in what is known as confrontation politics. Many of the techniques of confrontation were known, and publicized, via the news media and other means. Hence, the precedents, as well as the sources of information, for confrontation were well established. From personal observations, and the literature, it was noted that a generalized 
pattern appeared to emerge: (1) The Administration or persons perceived as capable of bringing about change in the institution were presented with requests or demands for black studies; (2) The institutional channeis for airing grievances are perceived as unresponsive, incapable of dealing with the demands of the students or interest groups, and finally, as exhausted with respect to the stated demands; and (3) The institution is challenged in a non-bureaucratic manner to change its existing policies, which in many cases implies a structural change. What was not fully understood at the time was that:

Demands for a black studies program are among the easiest for most institutions to accept in theory, but often present compiex problems in practice. 5

This study seeks to identify and to interpret some of the "complex problems" that have confronted institutions of higher education as they have sought to implement black studies programs. 


\section{CHAPTER II}

\section{REVIEW OF THE LITERATURE ON BLACK STUDIES}

In the brief period of time, 1965-1970, black studies programs and departments have found their way into the academic structures of higher education. However, these programs and departments did not germinate within the structures of higher education. The requests, and often cemands, for biack studies programs and departments have come from the clientele higher education serves: students in general; community interest groups; and organized stucient groups on campus. Nevertheless, many colleges and universities did respond to the requests, demands, and often overt acts of violence of advocates of black studies by establishing black studies programs and departments.

Higher education, in accepting black studies.programs and departments, has been presented with a series of educational crises, which are seen to be associated with black studies as an academic pursuit:

(1) Many colleges and universities have within their structures black studies programs and departments, with no adequate means to evaluate their performance as an academic pursuit; ${ }^{6}$ (2) Black studies has raised the question of who is competent to teach whom what subjects; more specifically, who should teach the Black Experience? Also related is the question of who is to decide who is qualified to teach what subjects; and (3) Black studies has seriously challenged the validity, applicability, and content of established disciplines within the educational system, e.g., history, political science, sociology, and psychology. Hence, black studies has challenged educators who have a vested interest in their 
disciplines and in the manner in which the educational system functioned prior to black studies.

A survey of the black studies literature to date indicates that the major themes of the articles dealing with the topic of black studies programs and departments have concerned themselves primarily with (1) the definitions of black studies programs; (2) the concepts and goais of the programs; and (3) the problems and criticisms of the programs, including questioning the validity of black studies. However, the assessment of black studies has been primarily from the perspective of programs that are within the system of higher education. As a result of this, questions about the precipitating events that have led to the developmental process of black studies programs and departments have largely been neglected if we can assume that there is no single event that can account for the development of black studies programs or departments. This study seeks to devote systematic attention to the developmental process of black studies programs and departments, to turn from histrionics to history, from social activism to social analysis.

The developmental process of black studies programs and departments is important for at least two reasons: (1) The developmental process has facilitated the entrance of an agent of social change (black studies) into the system of higher education, which in turn has introduced a series of educational crises which in all probability will have some inpact on the future of higher education; and (2) There is growing evidence that other minority groups, especially Mexican Americans (Chicanos), Indians, and women (although not a numerical minority), have begun to identify their position in society as similar to that of the black minority and are thus seeking new rights, including recognition in the 
systems of higher education. This seeking of recognition takes the form of programs in a format similar to black studies, i.e., women's studies, Mexican American studies, and Indian studies. Hence, there is the possibility that these groups may attempt to duplicate some of the processes that have been successful in providing black studies programs and departments for black students. In short, higher education is likely to see similar developmental processes or variations of these processes that have been responsible for black studies programs and departments.

Student unrest is not unusual in the American system of higher education, as indicated by Scranton (1970). Scranton notes that there were throughout the nineteenth century numerous incidents of disorder, iurmoil and riots which occurred within higher education. ${ }^{8}$ These protests were often based upon conditions and issues related to the specific needs or wants of the students involved--poor food, primitive living conditions and harsh regulations. Thus, complaints were closely related to conditions within the college or university that could be rectified by the particular educational institution involved. ${ }^{9}$

During the twentieth century the American college system witnessed its first important radical political movement among American college s:udents--the Inter-Collegiate Socialist Society--which, according to Scranton, had more members in the twenties than did the S.D.S. (Students for a Democratic Society) in the sixties. Some of the reasons for campus unrest in the 1920's were as follows:

During the 1920's there were campus protests against ROTC, denunciations of the curriculum for its alleged support of the established system, and attacks on America's 'imperialistic' foreign policy. 10 
The condition of campus unrest continued through the Depression and into the early 1940's. From the 1940's to the 1960's there was a period of relative quiescence on American campuses compared to the 1920's and 1930's. However, this twenty year period was disturbed in the 1950's when the Civil Rights Movement came to the forefront of public attention with several key issues and civil actions, e.g., the Montgomery, Alabama, bus boycott in 1955; and the turning away of a fifteen year oid girl from the Little Rock, Arkansas, High School by the National Guard in 7957.17

Prior to 1964, the "active" college and university student reacted to the crises pointed out by the Civil Rights Movement by moving from the campuses into designated communities, usually in the South. It is in these communities that the students attempted to challenge the existing system by joining groups that had strong reformist or radical orientations, and hence a political solution to the problem facing the biack minority.

In 1964 activist zeal increased. Scranton has identified 1964 as the turning point for higher education, due to what he describes as the Berkeley Invention:

What happened at Berkeley was more than the sum of its parts. The events on that campus in the autumn of 1964 defined an authentic political invention--a new and complex mixture of issues, tactics, emotions, and setting--that became the prototype for student protest throughout the decade. Nothing quite like it has ever appeared in America. 2

The year 1964 is also seen by Kerry Smith as a turning point for higher education. From this period into the $1970^{\prime}$ 's there has been a growing uneasiness on many campuses throughout the world. The source of this uneasiness did not start on the college campuses, but instead was 
reflected upon higher education as a symiptom of the social probiems present within the larger society. Kerry Smith states:

I cannot think of another segment of American life [higher education] where so many of those issues have been so vividly displayed: civil rights, poverty, drugs, black separation, and the overarching issue of national priorities. 13

Hence, since 1964, higher education has become a major focal point for conflicts troubling the nation.

In the early 1960's enroliment practices in education at all leveis were affected by Civil Rights Legislation. The Civil Rights Act of 1964, Title 3, "Desegregation of Public Facilities," sections 307401, laid the foundation for the change in education and specifically in higher education. The 1964 Civil Rights Act was followed by the 1966 Civil Rights Act, which clearly spelled out the desegregation guidelines. Titie 6, "Guidelines for Desegregation," requires:

1) Substantial achievements under the choice of desegregation plans;

2) Significant progress in desegregation of teachers and staff;

3) Progress in closing of small inadequate schools established for Negro students or other minority groups;

4) Simplified procedures and period reports from school districts to measure progress in implementing desegregation pians. ${ }^{4}$

Guideline 6 came under the jurisdiction of the Department of Health, Education and Welfare, which had the responsibility for checking on violations of the above stated Civil Rights statutes. In order to comply with the statutes of desegregation, public colleges and universities began to change their admission policies. The new admission policies had a variety of names, but their primary purpose was to admit students who did not meet the regular admission standards but who showed exceptional 
promise if given added attention. These admission policies were for minorities in general, but the black student was the prime beneficiary at the time.

"In the second half of the 1960's, enrollment of black students in American higher education more than doubled, increasing from 234,000 in 1964 to 492,000 in 1969, a growth of 110 percent." 15 With this increase came a new type of black student, which Vincent Harding calls the high risk student. The high risk students tended to be on the lower end of the socioeconomic scale, and very community conscious; they identified themselves more with the community they lived in than the academic community in which they studied. The community conscious black did not fit into the organized patterns of the campus nor the student organizations which were supposedly for the student's benefit. Hence, blacks formed their. own groups on campus which often excluded whites as members. Gallagher (1971) sees the black student organizations as having played a central part in promoting campus unrest and carrying out campus protest.

It can be seen that prior to 1970 the issue of race and black recognition was still in the forefront of incidents involving campus unrest:

Student protest and campus unrest occurred on 232 campuses in the spring semester of 1968-1969. Aithough other issues, such as the Vietnam War or parietal rules were often present, most (59 per cent) of these campus incidents were sparked by the issue of 'Black recognition' in one form or another. 16

It is during this period that many black studies programs came into existence, as is evident by the survey conducted by Fuller (1971): From a list of 864 schools belonging to the North Central Association, 306 schools were randomly selected to respond to a mailed questionnaire. Of the 
306 in the sample, 260 or 85 per cent of the total sample responded. Approximately one-half of these respondents reported that black studies was offered at their institution. Of this sample, 90 per cent of the black studies programs originated between 1967 and 1969. Only four school.s in the sample had black studies prior to 1965.17 Walter Daniels (1970) indicates that the rapid growth in black studies has presented problems at a11 levels of education. 18

Early biack studies (pre-1965) can be characterized as operating to serve what Charles Hamilton calls the "gap function"; the aim of this function is to correct the inadequacies in the recorded history of the black man in the American context. The position taken by blacks and other scholars who supported the gap function was that neither secondary nor higher education has adequately or accurately represented the experience and contribution of the black American. This inequity had been pointed out as early as the 1940's in the Journal of Negro History. ${ }^{19}$ Early black studies did not present the educational system with any problems that were unmanageable. The early experiments did not become unmanageable for two major reasons: (1) the number of black studies programs involved was not a significant factor, since ninety per cent of the programs did not originate until 1967-1969, and (2) the task of "filling gaps" attempted to add clarity and content to existing courses rather than to modify their basic structure. However, this was not the case with subsequent black studies programs.

Subsequent black studies programs, organized mainly between 1967 and 1969 , began to state a variety of reasons for their genesis. Charles Hamilton (1970), in an examination of forty college and secondary level black studies proposals, found that these proposals could be 
broken into six categories: (1) the gaps approach; (2) the functiona] approach, which seeks to prepare biack students to work in the black community; (3) the humanities approach, which is directed toward reducing racism among white students; (4) the reconciliation approach, which seeks to promote a spirit of cooperation between blacks and whites; (5) the psychological approach, which promotes a sense of pride in black students as they study and learn about their heritage; and (6) the ideology approach, which cultivates new ideologies, Third World organizations, theories of revolution, and theories of nation building. 20

The above alternatives cover the spectrum of stated goals and rationales for black studies programs and departments. However, unlike the gaps function, these subsequent goals have altered the basic academic structure and content of many existing courses, as well as initiated new courses dealing with the black experience. It is with the introduction of the black studies curriculum that black studies has come to the cricical attention of scholars, both black and white.

The general criticism of educators and other persons placed in the position of evaluating black studies has to do with the goals, aims, and purposes of black studies. One criticism is that black studies is without clearly defined objectives. Operating on the assumption that the above statement is valid, it can be seen that "measurement" of programs in an unclear status would be difficult if not impossible. However, answers to these two questions are paramount to the future of black studies programs and departments, given the present financial crisis in education in general.

The present state of black studies is also seen to be a function of its developmental process: 
The rapid escalating domands for black studies programs has been often in great haste, frequentiy without administrative and financial provisions required for effectiveness. There is little agreement on the specifics of such programs, but general terms as 'need' and 'relevance' recur in justification for black studies programs. 21

Also related to the developmental process of black studies programs and departments is the question of the prospective role of black studies in higher education. In comparison with other disciplines in higher education black studies is still in its developmental state. This is an inchoate state in which the transition from its present stage of operating procedures to that of operating in a manner similar to that of other academic courses is unclear. ${ }^{22}$

Recent criticism has concerned itself with the question of what the black graduate with a degree or certificate in black studies can have, with respect to gainful employment. This question has been asked in light of the observation that the course content of black studies in many respects deals with questions related to the Black Experience, rather than the traditional skills of other disciplines. While skills related to the Black Experience are finding some limited success, i.e., publications, poetry, and novels, film making and other media, these marketable skilis are not deemed sufficient by many scholars to absorb the present numbers of black students currently in black studies programs. The retort to this has been that black studies at the undergraduate level should act in a culturally supportive manner, while providing information about black people that would be useful in conjunction with other disciplines, e.g., pre-law, insurance, education, counseling, and in general where a. knowledge of black people would be useful to your chosen field outside of brack studies. ${ }^{23}$ 
A review of the literature further indicates that there have been many articles and publications having to do with specific elements of black studies programs and departments. These generally fall into three categories: (1) curricula and programs; (2) academic standards and accreditations; and ( 3 ) general criticisms and change in the educational system.

For many ethnic and racial minorities education has provided a way of battering socioeconomic status. In the case of racial minorities, namely, blacks, Chicanos and Indians, there have been individual socioeconomic gains.

There is general consensus among scholars and most of the public that the current socioeconomic and political situation of black people as a group should be ameliorated. But the question seems to be, is black studies the correct method of alleviating the current injustices? Scholars disagree. For example, James M. Rosser and Henry Wilson, Jr., conclude that:

It is paramount that higher education begin to produce Black graduates not only with intellectual skills, but also with a deeper knowledge of and commitment to their people and their community. 24

The authors further state that black studies is an appropriate and rational method of obtaining this goal.

Harold Cruse emphasizes a similar concern in the curriculum, stating that in order to correct the present status of black people, which is defined as cultural dominance by whites, black studies should reflect the theme of black nationalism. 25

A key theme often referred to in the literature is the concept of black identity. This theme can be found in the course content of classes 
as well as outside the classroom. Aivin Poussant states that it is paramount that the institutions of higher education give primacy to the development of consciousness and unity, which would in turn give survival to the black group. 26

There are other scholars who believe that black studies is not the correct method of approaching the problems that face racial minorities. Some authors have dealt with very specific segments of curriculum and not their potential implications. For example, Davis poses the question, "Is race a proper organizing concept for a curriculum?" Stated differently, is the 37 ack Experience a Tegitimate field of study? Answers to this question are crucial.

There have also been authors who have spoken to the issue of black curriculum from their particular perspective. Lewis in 1969 wrote an article titled "The Road to the Top is through Higher Education--Not Black Studies." From this perspective Lewis, focusing on the economic reality of ghetto economy, speaks specifically to the ability and skills necessary to recognize the given reality, not what should be, and feels these skills are not being learned in black studies. ${ }^{27}$

A second issue growing out of the curriculum and programs issue has to do with the academic qualifications and ethnic or racial background of instructors in the black studies programs. In short, what are the qualifications for teaching the Black Experience?

Hare, speaking from the perspective of the student, speaks of a "iightweight confrontation" between black students and administrators at San Francisco State College in 1969. The prime issue of the confrontation was qualifications of an instructor. The black students wanted a black historian from the community who was considered a scholar but had no 
decree. The Administration wanted a white historian, a Ph.D. Who had a series of publications in scholarly journals. The confrontation found bot' factions calling each other's applicant "unqualified." Hare states the students' perspective:

The biack students felt that if a professor of history couldn't understand that it's anachronistic in the present day--just now anyway at this particular point in the black consciousness movement, though maybe not ten or twenty years from now--for a white professor to teach black militant students black history, then the white professor doesn't understand the recent black movement. Consequently he doesn't understand black history, and therefore he's unqualified to teach the black history, regardless of how many Ph.D.s and publications he has in learned journals. 28

The above situation and rationale are not unusual as a request or as a demand. Black studies programs throughout the nation reiterated similar requests and demands.

It is in the context of separation that has brought to the forefront criticisms of such scholars as Kenneth Clark, who is said to have "resigned as a trustee of Antioch College in protest against the institution's Afro-American STudies Institution which enrolls only blacks."29 "Roy Wilkinson of the NAACP has threatened court action against any institution that uses public funds to set up racially exclusive programs. . . 30

A third major theme in the literature has to do with the structural changes that biack studies is having, and will likely have, on the systems of higher education. One such change is the admissions poljcies of non-white students.

Deans of admission have developed a variety of techniques of evaluating minority students by seeking to assess their academic potential. These techniques include having blacks evaluate the same student and comparing notes. In the case of non-white students who do not speak English 
Well, they are often totally assessed on the basis of persons belonging to that particular ethnic or racial group. There is also a group of culture specific (non-standardized) tests that admissions officers use; these are tests that speak to issues that are of general cultural knowledge plus several analytical problems which deal with the basic concepts of mathematics, language (cultural vocabulary), and the like. Higher education has also witnessed the "new" black, middle and lower class militant student who overtly challenges the educational system from different sets of meanings and values. Higher education has also witnessed the entrance of a "new" black student who is unlike the student of the 1960's who was responsible for the developmental processes of the sixties, whose actions are less militant, but also. unpredictable.

Only a few works have attempted to deal with all of the contingencies that have set the stage for the entrance of black studies into the college curriculum. Among the more notable of these publications have been those written by Skolnick, 31 scranton, ${ }^{32}$ and Valentine. ${ }^{33}$ Each has attempted to analyze black studies through developmental themes, solutions, and political implications.

Skolnick, in analyzing the contemporary situation, concluded that the violence and demonstrations that the American institutions were experiencing were the product of social, economic, and political inequities in society. Of particular interest were the themes of the black mijitant:

The theme of 'independence' is stressed rather than 'integration', and the concept of 'nonviolence' is being replaced by the concept of 'self-defense. ' 34 
It can be noted that both of these themes have appeared in the systems of higher education in the form of demands or requests. Independence is expressed in the form of asking for, and in some cases getting, autonomy. Self-defense was expressed at Corne11, where students asked for a 300c, Physical Education: "Theory and practice in the use of smal1 arms and hand combat." 35

Skolnick also systematically traces the four factors that have been responsible for the change in attitudes of blacks, attitudes that have also manifested themselves in the form of demands, and proposals, to higher education:

1. The failure of the Civil Rights movement to improve significantly the social, economic, and political position of most Negro Americans has led to doubts about the possibility of meaningful progress through law.

2. Urban riots in the $1960^{\prime}$ s which symbolize this frustration, have been met with armed force, which in turn has mobilized militant sentiment within black communities.

3. The worldwide revolution against colonialism has induced a new sense of racial consciousness, pride, and affirmative identity.

4. The war in Vietnam has diverted resources away from pressing urban needs and reinforced the prevailing skepticism about white America's capacity or interest in addressing itself to the social, economic, and political requirements of the black communities. 36

Scranton sees campus unrest as having arisen out of three main themes: (1) racial injustice; (2) the Vietnam War; and (3) the inadequacies in the universities themselves. However, unlike the National Cormission on the Causes and Preventions of Violence, chaired by Skolnick, the Scranton Commission on Campus Unrest was asked to analyze the data with the expressed purpose of offering solutions to alleviate the tensions in higher education. The latter Commission's major task was: 
1) to identify the principal causes of campus violence, particularly in the specific occurrences of this spring (meaning Kent State and Jackson State);

2) to assess the reasons for breakdown in the processes for orderly expression of dissent;

3) to suggest specific methods and procedures through which legitimate grievances can be resolved;

4) proposing particular steps which can be taken by government at all levels, by the administrations of institutions of higher learning, and by students, tirrough student government or otherwise, to minimize dangers attendant upon expressions of dissent. 37

The significance of the Scranton Report is that it does seek solutions to canipus unrest in a systematic way, covering many contingencies. Secondly, it further indicates that racial injustice is still in the forefront of issues reflected upon the campus, and acted upon by college students.

In a recent important article by valentine, ${ }^{38}$ there is an examination of the very clear political overtones that have been associated with the development and ensuing criticism of black studies programs and departments. The designers of black studies envisioned their innovative pian as a cultural force which vould enable the students to deal effectively with the strains and pressures affecting blacks throughout the larger society. Valentine sees this setting the stage for a conflict between the powerless supporters of black studies and the white power holders within, as well as outside, the academic setting. It is in dealing with this issue that Valentine clarifies the relationship between education and politics.

The above review of literature on black studies is admittedly not exhaustive; but the materials presented reveal clearly the significance of political factors in the black studies developmental process. The 
task now is to explore the relationship between education and politics in the implementation of black studies programs, mainly through the examination of four cases. 
A fundamental question is: What "actua17y" happens when students, faculty, and administrators from different cultures, with different systems of meanings, ideologies, and methods of approaching problems are asked (or forced) to work together to produce a document or formal agreement that would commit both factions to some form of action? The fina] concern of this study is with the long-range consequences of black studies upon higher education. It is hoped that in examining the developmental process of black studies, clues can be discovered that will indicate the possible impact on higher education.

The means of arriving at the stated goals of this study include: (7) an analysis of the precipitating events necessary to bring selected colleges and universities to the developmental process of black studies; (2) an analysis of the developmental process itself; and (3) a projection of the consequences of black studies for the future of higher education. The following sequence of events is used as an organizing principle: (1) the presentation of demands; (2) the perceived ineffectiveness of the bureaucratic process; (3) non-bureaucratic challenges to change the structure. The case study method was chosen in an attempt to reconstruct the history of four black studies movements at four distinctive types of campuses. 
Source of Data

The source of data came from four colleges and universities in the state of Oregon: (1) Portiand State University, Portland, Oregon; (2) Reed College, Portland; (3) University of Oregon, Eugene, Oregon; and (4) Linfield College, McMinnville, Oregon. These four institutions were selected for observation because of their contrasting institutional characteristics, and because of their locations. Two of these institutions are large (10,000 plus) and public--Portland State University and the University of Oregon. The other two are smal1 (1ess than 1,200 studenis) and private--Reed College and Linfield College. Two of these colleges are located in a large metropolitan area of approximately $i, 000,000$ population. Two are located in smailer cities of approximately 10,000 and 75,000 population. Data were gathered from six respondents at Portland State University; four respondents from Reed College; five respondents and a survey at the University of Oregon; and six respondents at Linfield College.

Respondents. Persons interviewed included a College president; deans of the Colleges, admissions officers, and other administrators; faculty and staff involved in the developmental process; black studies secretaries; and students who participated in the efforts to establish black studies programs on their campuses.

\section{Measurement Instrument}

Primary Data. From a review of the literature an open-ended questionnaire with qualifying statements was developed. The questionnaire was designed to elicit the respondent's assessment in the following areas: (1) attitudes toward the relevant events that took place; (2) black 
studies as an academic pursuit; (3) the respondent's sources of information; (4) the basis on which the respondent formed his opinion; and (5) the frame of reference from which the respondent sees the question. The questionnaire consisted of an eleven page booklet with twenty-two questions, eighteen of which had qualifying answers. The questionnaire was administered in the form of an interview, and typically took from one to two hours for the respondent to complete (Appendix A).

Secondary Data. Various memoranda and related documents, minutes of meetings, college catalogues, tape recordings, keynote speeches, college pamphlets, campus newspapers, and the like., were utilized.

\section{Procedure}

This author had observed during a previous study that key informants were invaluable for locating those non-academic personnel who were involved in the developmental process, and have since left the academic setiing. Hence this study made use of key informants. Key informants were discovered in the following manner: (1) by the author's having access to documents which named individuals involved in the developmental process of black studies; (2) informal relationships with members of the universities; and (3) relationships developed with black faculty at Portland State University, who referred or interceded in obtaining difficult contacts with other faculty and students located off the Portland State Campus.

From the' literature a written statement was developed, in the form of a thesis proposal. The proposal contained the following information: (1) title; (2) a brief review of the literature to date concerning the topic; (3) a statement of the problem; (4) the purpose of the study; 
(5) the source of data; and (6) method of data analysis. This written statement was then handed to key informants; at that time they were asked to: (1) make any comment they thought would be helpful, whether positive. or negative; (2) think about who could best respond to the information desired in the proposal; (3) be reassured that they would be contacted again after they had had time to read the proposal.

After giving the key informants a week to read the proposal, the author contacted them and asked for their opinions. Names of individuals who it was believed could be of help in explaining or telling about the developmental process at various institutions were solicited. A list was kept of the names that appeared the most number of times; these were among the first to be contacted.

At Portland State University all appointments with academic personnel involved in the developmental process were made in person. The procedure was as follows: (1) make an appointment for a specific amount of time, two hours if possible; (2) explain to the secretary what the block of time was for, and suggest that the interviewer would appreciate seeing any material that the respondent had concerning the developmental process.

Contacts made outside of the University concerning Portland State University were conducted in the home, or in a place that was convenient to both the respondent and the interviewer. The same procedure was followed: (1) make an appointment; (2) explain the purpose of the appointment, and ask for materials (written or otherwise) related to the developmental process of the relevant black studies program. 
Contacts at the remaining educational institutions--Reed College, Linfield College, University of Oregon--were made by telephone. The procedure remained essentially the same as above.

On the date of the appointment and after personal introductions, the interviewer restated the purpose for which the interview was being conducted and asked if the respondent had any questions about the purpose of the study. Occasionally there were questions; they ordinarily were concerned with how the information was to be used. In these cases the interviewer reassured the respondent that the information would be used strictly for the purpose of a master's thesis, and that there was no alternative motivation for gathering the data.

Prior to attending the appointment, the interviewer had filled out the person's name and status, as it related to the developmental process of black studies. After asking the question, the interviewer would record the response in a brief fashion in the spaces provided in the booklet. After the interview it was the interviewer's practice to ask the respondent if there were any questions that he would like to ask. The last question of the interview was, could you refer me to any other persons that might be able to provide information about the developmental process of black studies here at this College or University? Answers to this question often provided additional useful information. After leaving the interview, the interviewer would transcribe the received responses into longhand, and later into typewritten statements. The responses from the questionnaire will be used to determine if there is any relationship between the different types of educational structure and the type of program that develop at different institutions of higher education. 


\section{CHAPTER IV}

\section{GENERAL BACKGROUND INFORMATION ON FOUR SELECTED \\ EDUCATIONAL INSTITUTIONS: REED COLLEGE, LINFIELD COLLEGE, PORTLAND STATE UINIVERSITY, UNIVERSITY OF OREGON}

Initially, the selection of campuses for this study was designed to provide for contrast in size of student body, for distinction between private and public institutions, and for differences in size of community in which campuses were located. Subsequently it was discovered that the four campuses also exhibited differences in attributes of student organizations and in the form and quality of black studies programs. Before presenting the data from the questionnaire, let us share some of the basic information about each of the four campuses.

\section{REED COLLEGE}

\section{Relevant Student Organizations}

. Reed College is reported to have had a very strong Black Student Union (BSU); reportedly, thirty of the thirty-two black students in 1971 were members. The leadership of the BSU consisted of strong personalities, both male and female.

\section{Academic Structure of the Institution}

Reed College is a private college which is presided over by a Board of Trustees. Reed's academic structure is not marked by a high degree of formalized bureaucratic structure. At Reed the principal decisions concerning academic policy are put to a vote of the faculty. Because of the lack of bureaucratic structure, academic decisions concerning the policy 
of the college can be made quickly, and in a decisive manner.

Location of the College

Reed College is located in the Portland Standard Metropolitan Area; in which 22,000 of Oregon's 28,000 blacks reside. Also located in this Standard Metropolitan Area is Portland State University, a large public institution. This competing institution charges less tuition and attracts more of the students from the adjacent black community than does Reed College.

Current Status of Black Studies

At present Reed college has a black studies program, and three faculty who teach one or more classes related to the black experience.

\section{LINFIELD COLLEGE}

Relevant Student Organizations

The Black Student linion was not characterized as a strong BSU. One respondent stated that the first president of the BSU was a woman; the inference was that no black man on campus was willing to accept the role. The number of minority students was small, no more than twenty-five.

\section{Academic Structure of the Institution}

Linfield College is a sma11, private college without a complex bureaucratic structure. At Linfield the informal as well as the formal process of decision making on College policy is very important.

\section{Location of the College}

The physical location of the college is not conducive to attracting and holding minority students. There is no immediate black community. 
The 1970 Census 7 ists McMinnville, Oregon, where Linfield College is located, as having a total of only fifty-five blacks. None of the faculty or students seem to know where they are, or if they still are in McMinnville.

Current Status of Black Studies

Linfield is still in the developmental stages, moving toward some form of black studies program.

\section{PORTLAND STATE UNIVERSITY}

Relevant Student Organizations

The BSU at Portland State University was characterized as being a strong organization. The structure of the BSU consisted of two groups, a leadership core of eight members, and a membership of somewhat less than a hundred members.

The leadership of the BSU included people with work experiences outside an educational setting. Some of these experiences were transferred to the campus setting. Several members of the BSU were reported to be community organizers; one member reportedly had extensive experience in organizing black people as a Civil Rights worker.

Academic Structure of the Institution

Portland State University is a public institution which is part of a complex bureaucratic organization (higher education), which was in the Tate 1960 's in the process of changing its existing structural organization to include minorities in "some" manner. "The change is reported to have been brought about by acknowledgement of general civil rights needs and by pressures exerted by the Department of Health, Education and Welfare. 


\section{Location of the University}

Portland State University is located at the edge of the central business district of Portland. The major black ghetto is approximately two miles away. However, the University provides sizeable housing for blacks, through its Operation Plus program.

\section{Current Status of Black Studies}

At present Portland State University has a Black Studies Center. This Center consists of eight faculty members who teach one or more courses related to the black experience, and three staff members.

\section{THE UNIVERSITY OF OREGON}

\section{Relevant Student Organizations}

The University of Oregon is influenced by student government that has input into various committees and task forces that make policy which will affect the future of the University. For example, the Committee on Ethnic Studies was staffed by five students assigned by the Associated Students Union of Oregon. These students represented five ethnic groups: Black American, Native American, Mexican American, Chinese American, and Japanese American.

Leadership. Supportive services provide leadership and academic representation for five minority student groups on the University of Oregon campus. Three of these groups are the Black Student Union, American Indian Student Union, and Mexican American Student Union. Leadership is also provided by individual group leadership of the above student unions. 
Academic Structure of the Institution

The University of Oregon is a public organization and is itself part of a bureaucratic chain of institutions of higher education within the state of oregon. The complex structure of this bureaucracy is not conducive to quick change. Survival of the educational system is not dependent upon change in response to crisis. The University, like others in the system, has at its disposal a variety of ways to deal with crisis situations other than rapid change. This ranges from physically quelling any overt attempts to disrupt the institutionalized operating procedures to more subtle ways of negotiating for "some" rather than al] of the stated demands.

\section{Location of the University}

The University of Oregon is 1ocated in Eugene, Oregon, among a small but diverse population of ethnic minorities. The 1970 Census, General Population Characteristics, lists Eugene as having 2,353 minority individuals. But the actual number is larger than this, since Mexican Americans are counted as members of the white population. Of the 1 isted minorities, 743 are Black; 765 are Native Americans; 380 are Japanese Americans; 473 are Chinese Americans; and 639 are listed in the category of Other.

\section{Current Status of B]ack Studies}

At present, the University of Oregon has before the State Board of Education a proposal for ethnic studies, which at this writing is understood to be for the purpose of approval. The Search Committee is currentiy interviewing persons for the directorship of the program. 


\section{CHAPTER V}

CASE STUDIES OF FOUR SELECTED EDUCATIONAL INSTITUTIONS:

REED COLLEGE, LINFIELD COLLEGE, PORTLAND STATE

UNIVERSITY, UNIVERSITY OF OREGON

\section{REED COLLEGE}

At Reed the starting point for examining black studies was the Black Student Union. 'In the Fall of 1968, Alan,* then a black student at Reed, recalled in an interview that he attended a meeting held by the Black Student Union which introduced the proposal to develop academic courses on the black experience. Alan further stated that "We weren't just interested in any courses, but in black studies courses that would meet our needs."

A memorandum of that period disclosed:

According to Adam Tomson [then chairman] of the Educational Policies Committee, a sub-committee of EPC has worked with the BSU, and from this joint action a proposal evolved for a Black Studies Major with a required introductory course and additional courses within the present divisions of the college. This program would be administered by an interdivisional committee, as are other programs that are interdisciplinary.

This proposal was to be presented to the faculty at a meeting of December 2, 1968 and the faculty would have been asked for its guidance in the structuring of requirements at a meeting on December $9,1968.39$

Alan: "As the search committee got into the business of looking" at black studies courses, our awareness of the national situations as they pertained to black people increased. As a group we grew together.

*A11 personal names in this chapter, unless otherwise noted, are pseudonyms. All statements attributed to individuals are paraphrases of their remarks in interviews. 
In our research we were looking around the country to find out what other areas of the country were doing, and why. We were beginning to find out what a good program was about. Meanwhile, I attended a conference in [Washington] D. C."

(The conference referred to took place at Howard University, November 13-17, 1968. The title of the conference was "Toward a Black University." An estimated 20,000 attended. ${ }^{40}$ )

Alan: "It was at this conference that the theme--what being black is about--was clarified, and why it was important to have a black studies program that was controlled by blacks."

(At a meeting of the Educational Policies Committee during the week of November 18, the BSU delegates "seemed to think that decisions were being made 'too quickly', and advanced the idea that qualified consultants be called in to help design the program, " according to Professor Counts. ${ }^{41}$ )

Alan: "In late September or early October the BSU presented their position on why they wanted black courses at a student forum. It was understood that the BSU later would present their position to the faculty."

(On Friday, November 22 , the BSU presented the faculty with five demands and asked for a response at the Faculty. Meeting of November 25. These demands are summarized as follows:

1) That there be a commitment of a Black Studies Program of some sort, and that consultants be brought to the college to assist in establishing 'a viable program within the constraints of the Reed environment';

2) That funds be provided to bring consultants here to confer with the BSU, and that the funds be enough to keep them here long enough to develop the curriculum;

3) That the BSU have ABSOLUTE control in the selection of Black faculty for Black Studies; that the Black faculty receive at least the beginning minimum Reed salary; that no Black professor be removed without BSU permission;

4) That the Black Student Union have control over the curriculum until there are enough Black professors to do the job; 
5) That no courses dealing with peoples of African descent be taught at Reed without BSU permission. 42

On November 25, the faculty responded to the BSU as follows:

1) The faculty informs the Black Student Union that in accord with normal procedures, the Black Student Union may initiate discussion of personnel matters before the Faculty Advisory Committee and matters of curriculum before the Educational Policies Committee. The faculty notes that both of these committees have given full and prompt consideration to all Black Student Union proposals so far brought before them.

2) The faculty supports the bringing of consultants to the college, by the college as soon as it may be possible to do so, to aid the Educational Policies Committee, the Black Student Union and other interested members of the Reed Community in the current discussion of Black Student Union proposals.

The faculty document of November 25,1968 , failed to respond to the BSU's 7 ist of. (5) demands. ${ }^{43}$ )

Alan: "The response of the faculty seemed to be "Who were we [BSU] to demand anything?" At that meeting (November 22, 1968) the faculty didn't do anything, or give us any indication of what they were going to do. In the beginning we didn't know exactly what was going on. They started out by responding to our demands, but what they were really concerned about was who was going to be in control of this program--the students or the faculty. That was their main concern; ours was to get the black studies program.

"On Tuesday, November 26, 1968, the BSU called a community meeting to reiterate our position and five demands. On November 27 the BSU informed the faculty that they had failed to respond to the five demands that were presented on November 22. Between November 27 and December 1 , Reed recessed for Thanksgiving vacation.

"We had found out about the meeting that the trustees of Reed were having during this period. I don't remember how we found out, but we did. We had a meeting and decided to approach the trustees and see if 
we couldn't get them to change the minds of the faculty about giving us a black studies program. We then walked down the hall to where the trustees were having their meeting ard read our demands out loud to them. Anyway, we didn't convince them."

(A published report of this meeting conveys a somewhat different interpretation:

The trustees reaffirmed that they have delegated to the faculty and the president authority to determine educational programs at Reed. The trustees did express a wi]lingness to be further informed of the status of the BSU discussions at their next meeting, January 25.44 )

Alan: "After the meeting with the trustees, we called another meeting and decided that the faculty weren't going to respond to our requests. We figured the only way we were going to get them to respond to a black studies program was to put the faculty under pressure.

"We decided to take over the administration building on the third floor of Eliot Hall. We knew that this was where all the business offices were, where the payroll records and a lot of information that was pertinent to the operation of the College were kept. After we agreed upon that, we had other problems to contend with. We knew that the idea of taking over a building was not agreeable to all the brothers and sisters, so we agreed upon this solution. We agreed that only five of the brothers and/or sisters were going to take over a building, and that we weren't going to say which five or when the building would be taken over. But when the rest of the black students heard that the building had been taken over, they were supposed to support the strike in other ways. This was agreeable to everyone. Myself and four other guys went to the administration building. We had hammers, nails, chains, and food. We barricaded ourselves in the office." 
(Early Wednesday morning, December 11, members of the BSU barricaded the third floor of Eliot Hall, denying access to the offices of the president, registrar, controller, and dean of admission, as well as classrooms and facuity mail boxes. Pickets and demonstrators circulated on the remaining floors of Eliot and in other areas of the campus, and many classes were disrupted. An ad-hoc Radical Boycott Committee was formed by white students who declared support for the BSU set of demands by asking for a boycott of class.45)

Alan: "Three members of the BSU held a press conference to air their grievances. Subsequently the President of the College expressed his opinion to the media, stating that he had no plans for forcibly removing the students from Eliot Hall. We set up a 'liberal negotiating committee' between the faculty and the BSU."

(At 3:00 p.m. the President of Reed College called a meeting of the faculty. At that meeting the faculty issued the following resolution:

1) Demands 3, 4 and 5 of the Black Student Union are unacceptable to the Faculty. Acceptance of these demands would compromise essential principles of academic freedom. The Faculty intends to spell out its reasons for these conclusions in the. next few days.

2) The Faculty supports in principle the establishment of a program of Black studies. The search for faculty for this program shall be conducted and recommendations made to the FAC and the President from the faculty and two members appointed by the Black Student Union. Personnel of the Black Studies program after appointment to the faculty shall be subject to the normal criteria and procedures for promotion and tenure, although special procedures may be necessary for the gathering of data.

3) The Faculty continues to express its interest in bringing consultants to the College to aid in the development of black studies programs.

4) The Faculty regards physical interference in the educational process as a severe violation of academic freedom and as contrary to the principles of Reed College. ${ }^{46}$ )

The BSU responded to the statement of the faculty the following day, December 12, 1968. The faculty were asked to clarify its position taken in the meeting of Wednesday, December 11. The BSU stated that, 
"Until their reasons are explicated and a written guarantee of amnesty is granted to all those in Eliot Hall, the BSU cannot respond to their position statement." 47

Two members of the negotiating team were interviewed--Professors Barnes and Carr. These were two of the three-member faculty team that was to meet with members of the BSU. Their initial attempt on December 11, 1968, to negotiate was unsuccessfu1.

Professor Barnes: "I became involved in the developmental process on December 11, 1968, at the request of the faculty and students. I rather think I was selected because of my views, which were known. I didn't particulariy agree with all the things the. BSU was doing. While I was viewed as representing the interests of the faculty, in actuality my decisions weren't binding on the faculty. My function as I saw it was to relay the messages from the BSU to the faculty, and from the faculty to the BSU. In short, my role was more that of a communicator than a negotiator."

Professor Carr: "I became formally involved in the developmental process of black studies on December 11, 1968. However, I had already developed several informal relationships with the black students. After the occupation of Eliot Hall, I was contacted by one of the members of the BSU; he told me that he wouldn't speak with anyone on campus except myself. The faculty and staff at Reed knew where I stood on the issues at hand, that I was sympathetic to the BSU demands. So I suggested to the BSU member that it might be a better idea to have a committee, because the Administration would not let me represent their int'erest."

Thursday morning, December 12, 1968, the President of Reed College conducted an "open" faculty meeting with several hundred students in 
attendance. The President gave a review of the history of negotiations between the faculty and the BSU. He also referred to the merits of a blâck siudies program.

Thursday afternoon, December 12, 1968, the Reed Community Senate met and passed a series of resolutions as follows:

1) That the Senate strongly condemns the physical interference with classes and administration now occurring at Reed college.

2) That the Senate urges those who are physically interfering with classes and administration to stop doing so at once.

3) That the Senate urges the Black Student Union to resume negotiations with the Faculty's duly appointed committee.

4) That the Senate reaffirms the Community's sincere determination to contribute to the establishment of a Black Studies Program and urges the Black Student Union and appropriate college agencies to proceed actively with the development of a Black Studies Program. as soon as possible.

5) The Senate guarantees amnesty for the acts performed to date by those students presently occupying Eliot Hall.

6) The Senate affirms that the compliance with the class boycott is a matter of individual conscience. ${ }^{48}$

The BSU negotiating team did not meet with the faculty on Thursday,

but stated that they would meet on Friday, December 13, 1968.

On Thursday [December 12, 1968], President [of Reed] appointed a five-man ad hoc committee to draft a statement addressed to the BSU as to why the faculty had rejected Demands 3, 4, and 5 on the grounds of abridgement of academic freedom.

The statement was drafted and distributed to the faculty the next day, Friday. However, the statement of academic freedom was rejected by the faculty and the committee. The faculty was asked by other interest groups to redraft another statement Friday night for presentation at the community meeting Saturday.

The faculty statement was read by the President on Saturday morning [December 14, 1968]. 49

The negotiating teams met on Saturday afternoon and again on Sunday afternoon (December 14, 15, 1968). The next scheduled faculty meeting was for 
the evening of Sunday, December 75 .

Probably on December 14 informa 1 discussions between members of the Reed faculty and of the BSU, concerning the issues of occupation of El iot Hall and the BSU's demands, were begun.

The informal discussions that ensued are seen as paramount in the developmental process of black studies at Reed College, by all those interviewed.

Professor Carr: "When the blacks occupied El iot Ha11, several things happened: The role relations changed between the black students and the faculty. The black students and the faculty would meet to discuss the problems of what was going on, and for the first time the instructors were not protected by their roles as instructors and authorities on the given subject. They had to relate to students on a different leve1. This was a new experience for some of the professors.

"Some relationships were very warm, others were not. Faculty who prided themselves on their liberal position and who would make statements such as 'I'm not prejudiced,' and 'I don't care what coior a man's skin is, ' found themselves in conflict with the radical element on campus, which argued that those faculty were, in fact, not liberal. In some cases the incident in Eliot Hall brought out cases of latent hostility, but there was no violence involved."

Professor Barnes: "The effect that the talks had on the faculty was to convince the faculty of the BSU's commitment to their goal (black studies). I'm not certain of the real effectiveness of the talks, but in my opinion the talks had a weeding out effect. There were some faculty who had already had their minds made up, in terms of how they would respond on given issues. There was another faction of the faculty 
who stood in opposition to this group. There were some who wavered, or were uncommitted, but this was a small faction. So we really don't know the effect of the informal discussions. But I strongly suspect--and this is from the voting record on the resolutions--that a lot of faculty members didn't actually vote on the basis of necessity or conviction; they just voted."

After a series of informal talks between the Reed faculty and representatives of the BSU, the faculty met for three hours Sunday evening and passed two resolutions:

1) The faculty invites the BSU to name an academician to be agreed upon by both negotiating committees to provide advice and give assistance to the faculty and the BSU in resolving the present dispute concerning control over the initial stages of the Black Studies Program.

2) That the Educational Policies Committee proceed with reporting back to the faculty on the Black Studies Program, as they may deem appropriate, as soon as possible. 50

At this meeting the faculty also extended the fall semester to January 15, with grades due on. January 17, rather than the regutar date of December 30. The extension was made to allow students time to complete papers and to catch up on the administrative functions now disrupted in the registrar's office.

The faculty of Reed College passed the following resolution by a close vote on the following Wednesday, December 18, 1968:

The faculty supports in principle the establishment of an autonomous Black Studies Center under the auspices of the Reed Institute. It is understood that the Center would subscribe to the standards of Academic Freedom and Tenure. It is understood that the Black Student Upjon and consultants will assist in naming the first director. ${ }^{5}$

The following statement was signed by the President of Reed College and by Cynthia, a member of the Black Student Union, on December 18, 1968, 
after the faculty resolution was reviewed by the BSU:

We, the Black Student Union, accept the December 18, 1968 statement of the Reed Faculty with the understanding that control of the Black Studies Center will be placed initially in the hands of the Black Student Union, consultants, the Reed Trustees, and the President of the Reed Institute. Thereafter the control will be placed in the hands of the faculty of the Black Studies Center, the Reed Trustees, and the President of the Reed Institute. 52

Upon the signing of this document, the Black Student Union immediately vacated the third floor of Eliot Hall where its members had barricaded offices since early December 11, 1968. No damage was done to any offices on the third floor during that period.

The following statement by the President of Reed College was presented to the Reed community on January 27, 1969:

The board members [trustees] believe strongly that a Black Studies program outside the structure of the college (i.e., autonomous center under the Reed Institute) would not be as viable a program as one that is an integral part of the college. However, the Board also recognizes the unique need for Black Americans to control their own destiny, and felt it essential that the Black Studies program at Reed have an equal cooperatigh by the administration, the faculty, and the Black students.

The Reed BSU on February 5, 1969, issued to the faculty and the Reed community the following:

The BSU accepted in good faith the statements of agreement made by the faculty and President [of Reed] dated December 18, 1968 in regard to an autonomous Black Studies Center, and 54 expect the Faculty of Reed College to honor this agreement. ${ }^{54}$

In a meeting on February 7,1969 , the faculty responded to the resolution made by the trustees on January 25, 1969:

The faculty acknowledges the resolution of the Board of Trustees to support the creation of a Black Studies Center. It reaffirms its determination to contribute to the development of Black Studies at Reed and desires to continue discussions with the Black Student Union, about the current status of Black Studies at Reed. For this purpose the faculty designates the four members in a similar discussion in December, 
and requests the BSU to name four of its members to meet with these faculty. It is hoped that the faculty members of this coimittce will be able to report on these discussions at the mosimg of Fubluary 10.55

The joint committee of Reed BSU and faculty which was given the responsibility of establishing a black studies program began negotiations. These proved to be fruitiess.

Alan: "In time the BSU began to view these meetings as a'timeconsuming device--an evasive tactic. Late in February progress toward a black studies department was halted. On February 25 , the BSU held a press conference to let the public know what was taking place.

"We brought James Turner up from San Francisco as a consultant, and we were in contact with Bill Johnson at San Francisco State. We finally found a potential director. He said he would be willing to accept a co-airectorship with another person whom he had in mind. The BSU found this acceptable and submitted the applicant for the candidacy of director of black studies. However, the faculty did not find the candidate acceptable."

In disgust, the BSU released the following statement to the press on February 25, 1969:

Since the Faculty's December 18th vote for an Autonomous Black

Studies Center, all actions taken by the trustees and the faculty have been unacceptable, evasive, and meaningless.

Therefore, the BSU is taking the following steps:

1. We are writing the national association of AfroAmerican educators to ask them not to refer any professors to Reed;

2. We are writing all of the Black Colleges and asking them not to refer any professors to Reed;

3. We are writing all black college students who have applied to Reed and encourage them to try to get in another school that will provide them with a meaningful education. 
The BSU will block any attempt of the school to set up a Black Studies program that is not controlled by Black people.

\section{Reed College \\ Black Student Union. 56}

The following day, February 26, 1969, an unknown number of white students held a demonstration and sit-in in one of the offices of the Reed trustees. Their demand was that the faculty immediately implement the faculty resolution for an autonomous Black Studies Center. All but five left voluntarily; those who remained were peacefully removed by police officers and charged with trespassing. The charges were later dropped. 57

On Thursday, February 27, white students at Reed took over the President's office. They were finally persuaded to leave on Saturday, March 1. No black students participated in the above demonstrations. 58

Alan: "An attempt was made on the part of the President to bring in a black instructor that the President knew. However, the black instructor did not know all of the previous events that had occurred on the Reed campus. After this black candidate was briefed by the BSU as to the previous events, the BSU spokesman explained to the applicant that he was not acceptable, although this meant no personal reflection on him as a person.

"With the President's candidate found unacceptable to the BSU, and with the BSU's candidate being unacceptable to the faculty, a stalemate developed and continued until the end of the spring term. The money for a black studies faculty position remained committed for the coming academic year, 1969-70. The Reed BSU was faced with the task of finding a director for the black studies program. So, in the summer several students got together, and we decided to see if we couldn't get the 
person who is now our present director to accept the position. He did, and in the Fall we had a program."

\section{LINFIELD COLLEGE}

At present Linfield College does not have a black studies department, or any organized program of study in the field of black studies. Linfield is currently in its developmental stage of moving in the direction of black studies courses. Linfield started this process as early as the 1967-68 academic year. This movement toward black studies has been slower than on the other campuses studjed.

From interviews with key personne?, minutes of faculty meetings, pamphlets, and a speech delivered to the faculty by one of the deans of the College in May of 1972, this developmental stage can be partially reconstructed.

Professor Del 1: "In 1966 there was a summer course offered which dealt with the black American; to my knowledge this was the first course of this kind offered at Linfield. Later there were temporary courses opened to the community which dealt with black history and culture. These were evening courses, offered in 1967 and 1968.

"One major strand that contributed to bringing blacks to Linfield started in the Spring of 1967. That year I was approached by Earl, who at that time had made some financial arrangements between the valley migrant workers, who were mostly Mexican Americans, and the Federal government. As I remember, the financial arrangements were made so that the heads of households could attend college and be paid for their attendance by a joint venture between the Federal government and the migrant workers. As we talked, I found out that Earl had been working to raise 
the educational level of several of the migrant workers, and he felt that they were ready for college. The problem was that now the College Administration had to be convinced that with some help these workers could benefit from, and make it through, Linfield. I agreed to intercede for Earl and do what I could. The Administration did agree to give the workers a chance.

"Almost immediately I began to recognize the relationship between the Mexican Americans and the blacks, in terms of what could be done. This was one strand of events that I think made the idea of getting more b]acks on campus more acceptable.

"Another major strand happened rather suddenly when one of the well-known black athletes on campus suddenly became highly aware of his b.lackness, and began to display racial consciousness. He and another black who was attending Pacific College apparently experienced the same thing together. This black athlete made charges that Linfield was prejudiced. I sort of felt that this student must have had some feelings for Linfield as a college, or else he wouldn't have done what he did for the College. This student, partly as a challenge, partly because of commitment to what he believed, initiated a program of action to attract black students to Linfield. Later a committee was formed, with Professor Phillips as chairman; it was called the Action Committee.

"There was opposition, but I think mostly to the idea itself of having or bringing blacks on campus. But in Apri1, 1968, with the death of Martin Luther King, Jr., the Action Committee became galvanized. The question simply had to be posed to the faculty: Did this man die in vain? This may sound like an exploitation of King's death; in some ways it was. But given the faculty we have here the question was asked, and 
the faculty responded.

"After the death of Martin Luther King, Jr., the MLK Scholarship Fund was established. We received $\$ 10,000$ from a Baptist Fund and other contributions came to, I think, about $\$ 400$.

"The Director of Admissions couldn't find any blacks, but the athlete previously referred to brought a bus load of black students to the campus. However, we didn't get any of those students. Finally a black girl on campus was able to get five black students to come to Linfield."

On May 6, 1968, the Action Committee presented to the faculty their outline for attracting black students to Linfield.

The minutes of the Faculty Meeting of September 2, 1968, stated that the Action Committee had advanced to the organizational stages, and were prepared to deal with their stated goal, which was the recruitment of non-white students. The chairman of the Action Committee, with the assistance of two college girls, had presented the action program from the standpoint of its history on the campus, its developing program, recruitment methods used. The scholarship fund was stressed. According to his report, some $\$ 10,214$ had been raised to finance the program. ${ }^{59}$

In these same minutes of September 2, 1968, the following item appeared:

Item E. Page 6. THAT QUALIFIED, NON-WHITE FACULTY BE ACTIVELY SOUGHT. We heartily recommend that the faculty endorse the proposal and ask that department heads, the academic dean and the president make a special effort in this case. Discussion followed. Motion carried.

It became apparent that the Action Comittee had made several gains as far as moving through the academic structure was concerned, and gaining concessions from the faculty. This occurred in 1968, yet Linfield 
College did not have any substantial number of black students on campus at that time. Why were there so few black students at Linfield College? Several explanations were offered: (1) the location of the College;

(2) the lack of continuous effort on the part of the Action Committee; and (3) financial exigencies.

The location of the College is McMinnville, Oregon, a town that is experiencing a declining population. The town does not have any black community to which a black person could relate. In fact, most instructors on campus can't even remember seeing a black family in the town. The McMinnville population offers a sharp contrast to that in most of the areas from which the college's black students have been recruited, places such as the San Francisco Bay area and Los Angeles.

Adjustment by black students to life in McMinnville is eased somewhat by the Black Student Union and the Admissions Officer. This fact is exemplified by a publication titled, A Communication to Prospective Black Students by Black Students. This communique speaks specifically to some of the above issues, and attempts to prepare the individual for the life that the college and the community have to offer the black student.

[McMinnville is] a nice place to visit but I wouldn't want to live here. As a school Linfield is great, but as a community it is sick; but the world is sick, so that shouldn't upset anyone. This place is no different than any other al7-white school, so why come here instead of an all-black school? . .61

The second theme, the lack of consistent effort on the part of the Action Committee, was expressed in terms of what happened to the Action Cormittee at a particular point in its growth.

Professor Word: "The Action Committee was mobilized for a situation that never occurred. The faculty was ready to give the committee what they were asking, and in many cases did. As the goals of the Action Com- 
mittee became realized, the Committee started to disband."

The third issue raised was financial exigencies. This was a theme that recurred throughout the interviews.

Professor Word: "The financial exigencies that the College, and subsequently the faculty, were experiencing [the faculty had not had a raise in five years], coupled with a high degree of social interaction among the faculty, had produced unity among the faculty. Therefore, any new program or proposal that required the expenditure of funds already scarce, would not receive an affirmative vote from the faculty."

The Admissions Officer of Linfield explained that before he was given the responsibility for recruiting blacks, he had not developed any specialized technique for such recruitment. He recalled his experiences of not being exactly sure where to start. But he did subsequently acquire the skills. He also spoke of the practices of black students who were presently satisfied at the College, including how they coaxed other black students from their neighborhood or town to attend Linfield College. The Admissions Officer was also involved with other activities on campus that pertained to black students and hence was unable to devote his full attention and time to the job of recruiting blacks to Linfield. The recruitment of blacks to Linfield remains slow, but the number is gradually increasing.

At present there are approximately twenty-five full-time black students attending Linfield College. This number is expected to double in the coming academic year, 1972-73. It is estimated by the Assistant Dean of the College that by the 1973-74 academic year the full-time black students attending Linfield will have increased to one hundred or more students. Currently there are no full-time minority faculty at Linfield. 


\section{PORTLAND STATE UNIVERSITY}

Mr. Lawrence, a former student and the first director of the Black Studies Center at Portland State, described conditions on the campus in 1967, before the Black Student Union was: formed.

The total number of full-time Afro-American students in 1969 was less than fifty. There were three faculty members of African descent; only one of these taught courses related to the Black Experience. Likewise, the total number of courses (taught mainly by whites) in any way relevant to black people, never exceeded four. A maximum of two black athletes could be found on any of the University's major athletic teams, in spite of the fact that the Portland Interscholastic League produces almost all black athletes to come out of Oregon high schools. In 1967 there was no formal BSU, only a smal1 group of concerned students, whose only available focal point was Dr. C. Eric Lincoln's black sociology class. The only black event or speaker to occur that year was the appearance of Stokely Carmichael, sponsored by this small group.

In 1968 the Black Student Union became formalized and consisted at that time of approximately eight active members. Herein lies one starting point for the change which led to the development of the Black Studies Center at Portland State. During the same year the Oregon State Board of Higher Education began to express awareness of special needs of minorities in higher education. It is imperative in understanding the genesis of black studies to note that there are two perspectives of how black studies at Portland State came into existence.

The faculty and staff of Portland State University who were interviewed see the developmental process of black studies as following a "normal" bureaucratic sequential development: (1) in response to the State Board's interest the initiation by the Portland State University President of a task force, starting in May, 1968, and ending in December, 1968; (2) development of a sub-committee to study the feasibility of a black studies program; (3) the elevation of this to full-comittee status 
by the President of Portland State, and the move into the formal stages of the developmental process leading to black studies; and (4) the culmination in the establishment of a Black Studies Center and Program.

BSU spokesmen do not perceive the, same sequence of events. They responded within the context of a total plan (to be explained) which was interwoven with the decision-making involved in establishing the black studies program. For the BSU the correct sequence of events for their plan was: (1) the President's task force; (2) Operation Plus; (3) Portland State Educational Center; (4) Martin Luther King, Jr., Scholarship Fund; and (5) the establishment of the Black Studies Center and Program. Administrator Downs: "Many things happened in 1968 that I don't think could happen again. The nation seemed to be in turmoil, and people looked to the national news to see what new and sometime unique thing had happened in the U.S. The State Chancellor's Office indicated to Portland State University that we should consider admitting three per cent minority students. Our enroliment of minorities at the time was very low. The President of the University authorized a committee to check into the various possibilities of how this request could be implemented. The committee grew into a task force charged to consider a wide variety of possibilities, and black studies was one of them. Other possibilities were Operation Plus, and the Community Center. A separate committee was then developed to explore the feasibility of black studies."

John, a member of the Black Student Union, recalled additional events in 1968.

John: "We were aware of the programs that were developing from the task force for the disadvantaged. From the beginning we really were 
thinking of a full program; all of the steps leading to a black studies program were felt necessary by the BSU. We knew we needed to recruit students to the campus, keep them in classes after they got there, and continue to encourage them to get through college. For instance, if we got some students into college on the three per cent program, they would probably need some form of tutoring; so we established a tutorial program. Tutoring is now taking place in the very space at Portland State University that was supposed to be for minority students, only now it's for all students. Second, there had to be some sort of residence established if the student was to stay on or near the campus. That was what Operation Plus was about. Third, if the student was to remain on campus, he needed some money to pay his tuition, and that's where the MLK [Martin Luther King, Jr., Scholarship Fund] came in. The Black Studies Program was our goal, but there were other things that had to be done and dealt with prior to black studies."

Mr. Lawrence, the first Black Studies Program Director, has written about the tactics used to arrive at the goal desired by the BSU:

The tactics used by the BSU were similar to those employed by black college students on white universities around the country. Tactics centered around the concept of open confrontation and conflict. There was the use of Black Cultural Rhetoric, non-violent and sometimes violent demonstrations. ${ }^{63}$

Earliest confrontation developed around the issue of Project Teach. In June, 1968, Project Teach (Operation Plus) was established as a $3 \%$ program for students who did not meet regular admission standards, but showed exceptional promise, if given 64 added attention. The majority of the students were black. ${ }^{64}$

Additional light was shed by Pete, a BSU member.

Pete: "It had been brought to our attention that the task force had actually gone into the planning stages of the three per cent program 
for blacks and there were no blacks on the committee. When we found this out, BSU members went into a committee meeting and told the members that there would be no three per cent programs unless blacks were involved in the planning. I remember arguing with one of the members of that committee about this very point.

"From that point on black people did become involved in the three per cent program and as a result, one of the administrative representatives of the program proposed by the committee was a black man, who had formally been a member of the BSU."

It was subsequently learned that there was a black man slated to be on that committee, but that he was not perceived to be black in his commitment. Stated differently, there were some questions as to whose interest this person was representing.

Professor Jules, an administrator, recalled the BSU entry into the committee meeting.

Professor Jules: "I remember being in the room when members of the BSU entered and read some demands. I' remember thinking at that time that those techniques wouldn't work, only to find out later that they did work. The person who was responsible knew very well what he was doing, and that these techniques would work. Portland State really started to experience trouble from the black students shortly after the date that they received recognition from the college, in February, 1968, as I recall.

"BSU members also conceived of the idea of what is now the Portland State University Educational Center, located on Union Street. I't was originally called Albina Presence." 
john: "We learned that the administration was willing to grant some of the concessions that we were asking for, although reluctantly, and usually at their discretion and choice of sights and locations. We found this out with Albina Presence. The place that they selected for us had hardly any head room, was located in a basement, and there was only one door. Several members of the BSU were supposed to teach in. that basement. We attended a meeting, and while we were there, a person started reading off names, asking if members of the BSU were willing to teach there. We all told him "no," we weren't going to teach there. Then someone asked him exactly who he was. He replied, 'I'm taking over for the President of Portland State University.' What had happened was that somehow the President's instructions had been misinterpreted.

"If the President had gotten his way, the courses would have been offered through D.C.E. [Division of Continuing Education]. That wasn't what we had agreed upon; we were asking that the courses be offered by Portland State University. When this was discovered, the BSU went looking for the President. He was located in a meeting that was in progress, taken out of that meeting, and returned to the place where we were meeting and asked to explain the present situation.

"The result was that the building was changed, and the courses were offered by Portiand State University. But we learned that as long as we were asking for concessions which were external to the University, we were getting some results. But when we asked for programs that would modify the educational structure, we met all kinds of resistance.

"Part of the reason that the administration granted the concessions they did was because they knew that we weren't hampered by any bureau- 
cratic structure; they knew that we could organize students on very short notice if we needed to. On several occasions we did, and we would pay the faculty an unannounced visit during their committee meetings. They didn't like that at a11. But the faculty and administration were always making plans for the future of black students, but we wanted to have a hand in the development of these plans and the faculty weren't in a habit of inviting us to the planning sessions."

"Albina Program Homeless," an article in the student newspaper, the Vanguard, February 14, 1968, corroborates the above account by John.

It is important to the reader's understanding of the developmental process of black studies to note that members of the BSU involved in the Black Studies Council were simultaneously involved in other committees on campus. Hence the members of BSU were interested in the interrelation of former programs and the developing program of black studies.

In November, 1968, John attended a conference in Washington, D.C., as a representative of Portland State University. The theme of the conference was "Toward a Black University." It was at this conference that many of the nebulous concepts about the Black Experience and its content and methods of studying it were clarified to the satisfaction of many black students and educators.

The conference started on November 13 and ended on the 17 of November. Some of the more notable and scholarly members participating in the conference were Andrew Billingsly, Vice chancellor of Minority Program, University of California; Stokley Carmichael, author and speaker; Alvin Poussant, Associate Professor of Psychiatry; Floyd McKissick, CORE; Nathan Hare, Director, Black Studies Institute, San Francisco State; and LeRoi Jones, poet and playwright. 
John: "The participants at the Washington conference spoke to the social aspects of moving from an informal stage of development to the formal stage. The problem was one of resocialization for both groups, the members of the BSU and each local faculty and staff.

"This process of socialization took most of the time, in fact about ninety-five per cent of the time, when BSU got together with PSU faculty. For example, when we first started the program, the faculty and staff of Portland State wanted to call the program Negro Studies; we didn't go for that. But they couldn't "see" what was wrong with the idea of calling it Negro Studies. Then they wanted to change the name to Afro-American Studies. For some reason, they didn't want to call the program Black Studies, when that's exactly what we wanted it to be called. Finally they agreed to call the program Black Studies."

Professor Kells: "There were many social problems that had to be worked out on the part of both groups. Many of the faculty were undergoing personal adjustments to meet the needs of the task that was before them. I experienced tremendous personal growth from participating in the developmental process of Black Studies. There was a time when, if you called a black man black, it was an insult. So you learned to use the term Negro and that was how you showed respect. Now if you use the term Negro it is an insult to some blacks, and the word black is accepted and preferred to Negro. There were also some other problems that had to be ironed out, problems of procedure, that were necessary to the developmental process. One of the questions that came up early in the meetings was who was going to keep the minutes of the meetings. This had to do with the editing out process of meetings, of determining what is and what isn't important. This was solved by the members of the committee agree- 
ing to have the minutes tape recorded."

The author was able to acquire five such tapes of the proceedings that transpired during the 1968-69 academic year. (See Appendix B for transcription of selected parts of these tapes.) There were reported to be other tapes but they have not been located. Some of these meetings were transcribed into minutes and distributed in the form of a memo to members of the committee.

The files of Professor Kells indicate that he was receiving information from all parts of the United States pertaining to demonstrations, occupations, and programs that were in various stages of their development, with respect to black studies.

The subcommittee which was exploring the feasibility of black studies was elevated to the status of full committee by the President on January 10, 1969. The former Black Studies Committee thus became the Black Studies Council. At that time the President specified the task of the Black Studies Council:

1) Current catalog courses which relate to Afro-American studies courses should be audited to determine the necessary augmentation with which to develop an AfroAmerican curriculum.

2) Defining the configuration for an adequate Black Studies

Center, the relative balance particularly between the divisions of social science and humanities and how to phase in the Black Studies degree.

3) To determine the relationship of this Black Studies curriculum to another aspect of PSC's commitment to inter-institutional cooperation with Reed, University of Poriland, Lewis and Clark, and Marylhurst.65

As early as December 23, 1968, the BSU had announced to the subcommittee that they had already developed a tentative curriculum, which they would supply to the members at the forthcoming meeting on January 6 , 
1969.

The minutes of January 28,1969 , indicate that at that time the Council was split into two sub-committees, the rationale being "to give direction and expedite our considerations." There were: (1) SubCommittee on Departmental Guidelines, and (2) Sub-Committee on Black Studies Center.

The minutes of the Black Studies Council indicate that on February 4, 1969, the BSU submitted a document to be read into the minutes of the meeting. This document was a working paper, allocating responsibility and procedures for black studies and proposing organization of an Action Committee.

Minutes of the Black Studies Council dated February 18, 1969, indicate that

[John] asked whether or not the council was actually working toward the establishment of a Black Studies program. [Mr. Kells] commented that there had not been very much progress to date. He said that he would be appearing before both the Council of Academic Deans and the legislators this week.

Some discussion followed concerning the role of the Council in the area of faculty appointments. [John] suggested that we inform departments that we do not believe that a degree is a necessary qualification. 66

The minutes further reveal that John, Pete, and Ed presented the Council with an outline of specific areas which needed attention before the Council could proceed in the establishment of a program. The issues which needed resolution included:

1) Narne; 2) What division (It was decided that Black Studies should be outside the divisional structure); 3) Objectives; 4) Justification; 5) Other programs; 6) Professional use of the certificate; 7) Interest 70ca71y; 8) Advantages and disadvantages if the program is not offered; 9) Core courses; 10) Resources for implementation of the program; 11) Course description. 67 
Resolution of these issues was assigned to specific individuals on the Council. Their puposic was to conduct investigations and to prepare recomendations for the Black Studies Council. The results appeared in various minutes of the Black Studies Council. Of particular interest are the minutes of March 7, 1969, which deal with the promotion of the program among other academic disciplines within the University.

The initial statement in that meeting refers to the visit of Dr. Franklin, a black studies consultant, to Portland late in January of 1959. At that time Dr. Franklin stated that the prospective black studies program should be of high academic content. This suggestion was given considerable consideration in the planning of the proposal for presentation to other departments. Individual reports were presented through April and into May.

In May, 1969, the minutes of the Black Studies Council indicate that the chairman called to the attention of the Council a timetable. The timetable consisted of a five-point program which had to be prepared by June 7 of 1969 .

The five points to be covered were: (1) Developmental pilot courses; (2) cultural programs developed to inform the community of many facets of the Afro-American experience; (3) The hiring of a director; (4) Seeking teaching staff; (5) Location of physical housing for the program.

Of prime importance to the Black Studies Counci] was the hiring of a director. The minutes of the May 23 meeting express this concern by noting that black studies directors are at a premium. By agreement of the Black Studies Council the black students were to have a hand in selecting the first black studies director. John indicated that it was 
the intention of the Black Student union to recommend only one candidate for the position. The first person proposed by the BSU met with acceptance by Portland State University. This was in late August, 1969.

It was within the power of the President of Portland State University to use the experimental numbers for academic courses for the coming fall term. Beginning in the Fal1, 1969, Portland State University estabTished an Experimental Black Studies Program. At this time there was a list of courses that would be accepted under the certificate program.

At this time, Portland State University had not submitted a formal document to the State Board of Higher Education concerning the permanent status of the Black Studies Center.

While there was some generai agreement, there was no specific agreement on what should go into the final proposal. There were two basic proposals offered for consideration of the Black Student Union. One had been drawn up by a member of the Black Studies Council, the other by the Black Student Union. There was a third faction which attempted to synthesize the best of both programs. This third faction responded to two paragraphs in the proposal submitted on June 16, 1969. One paragraph stated that the program must be revolutionary. The second paragraph stated that the program must be nationalistic. An argument deveioped centering around these terms. Members of the Black Studies Council argued that the State Board of Higher Education would not accept the Black Studies Program with those phrases. Black Student Union members argued that the rationale for the terms were valid and fully explained. The Black Studies Council members retorted, "As soon as they see 'revolutionary' and 'nationalistic,' they are going to 'turn off,' and they won't see your rationale, or accept the proposal." 
What ensued was a hot7y contested debate on the part of members of the tr:o groups. Reiuctantly members of the Black Studies Council agreed to include the two phrases: The first proposal submitted by Professor Finn, a committee member, did not meet with the Council's acceptance, and what followed was a series of drafts and re-drafts of the program subnitted by the Black Student Union.

This continued until mid-March, 1970, at which time the final proposal was submitted to the State Board of Higher Education for approval. The program was approved and in the Fall of 1970 the term "experimental" was dropped and the program became the Black Studies Program.

\section{THE UNIVERSITY OF OREGON}

Through interviews. with various participants; reviews of the student newspaper, the Emerald; study of minutes of various meetings on ethnic studies; and examination of two proposals that were submitted for approval to the President of the University of Oregon, materials for the reconstruction of the development of black studies at the University of Oregon have been collected. (One of these proposals is the formal proposal for ethnic studies, which at this writing is before the State Board of Higher Education.)

A review of the daily Emerald from June, 1967, to June, 1968, indicates that at one time the University of Oregon was following a path that might have culminated in a black studies department rather than an ethnic studies program.

The Emerald carried severa 7 articles in 1967 pertaining to the discrimination in housing on campus and, in some cases, off campus. In the April 15, 1968 issue of the Emerald a headline read "Black Students 
Air Grievances." These grievances were in five categories: (1) athletics; (2) dormitories and related areas; (3) finances and related areas; (4) curriculum; (5) general grievances. Under Item 4, curriculum, there were four complaints, summarized as follows: (1) the lack of AfroAmerican history; (b) the absence of Swahili and other African languages; (c) absence of African studies; (d) the lack of black professors and black graduate students in the University.

Copies of the text of the grievances were sent to CORE (Congress of Racial Equality), SNCC (Students Non-Violent Coordinating Comittee), Headquarters of the Governor, Office of the Chancellor of Higher Education in Oregon, and Black Student Unions throughout the West.

On Apri1 18, 1968, the Emerald carried a front page story of the University President's forming a committee on racism in response to the grievances of the black students. The committee was to be divided into six sub-committees corresponding to the grievances reported earlier on April 15 in the Emerald.

On April 30, 1968, the Emerald carried a story to the effect that Nathan Hare and James Garret would visit the University to help faculty and students interested in developing black-oriented courses.

On May 21, 1968, an Emerald caption read, "Racism Exists in Dormitories." On May 22, 1968, the Emerald carried the front page story, "Committee Proposes Black Studies School," as well as the complete text of a report by the Sub-committee on Racism, which included:

In eliminating racism at the University of Oregon, it is plain that we must modify the existent and currently racist patterns of institutional behavior which allow students both black and white to pursue careers within established departments and professional programs. It is essential that the curriculum as well as the faculties of the departmental and professional schools reflect contemporary reality. 
Since it is more exactly in the institutional structure that we find racism so entrenched, we recommend that representatives of the BSU be appointed to the various curriculum committees of the departments, schools and colleges, in order to instruct the white members of those committees about the racism in existent courses and about the probability of racism offered in addition to the curriculum. 68

The logical question that is derived from the above review of the black issues of the Emerald is: How did the thrust toward black studies get redirected toward an ethnic studies program? Unfortunately, the political maneuvers involved in changing the thrust is a bit beyond the scope of this study. This initial thrust has been mentioned, however, to indicate that: (1) The University of Oregon did not evade the prevailing tide that swept the nation in 1968, following the death of Martin Luther King, Jr.; (2) The University did find itself reacting to pressures brought about after the death of Martin Luther King; (3) Because the University did not act in what was thought by blacks to be the best interest of the black students in the University, some doubt was cast on the sincerity of the following ethnic studies program; (4) Feelings of insecurity on the part of the faculty and administration, coupled with the finances involved in the program, have succeeded in producing a swift undercurrent that most of those interviewed referred to as "political issues" but did not wish to elaborate further.

The starting point for ethnic studies was November 5, 1969, at which time the President authorized establishment of a Committee on Ethnic Studies. The first meeting was called to order by the chairman on Thursday, February 19, 1970. It was at that time that the goals of the Committee were explained:

a. A member of the three ethnic peoples (this committee is concerned with--American Natives, B]ack Americans, Mexican Americans--) trained to return to his own people to help 
With their problems? Social workers etc. . .

b. Education for black people in the ir own history and cuiture so they may identify with themselves and with black people who have contributed to the American culture and economy? A time of "preparing for the future and looking at the past.". .

c. To plan schools, possibly using English as a second language to educate American natives to prepare them for teaching to ease their people into the mainstream of American life, . . 69

Minutes of the Committee on Ethnic Studies dated March 5, 1970, indicate concern over the meaning of "ethnic studies":

A committee member explained that there are several meanings of "Ethnic Studies": 1. To lead to a unified America where 211 races study all races culturally and historically. 2. To "set things right" meaning to "make up" to the races which have been neglected and "wronged."

He then stated that this university could not possibiy do the latter--it is a state school and does not have the background, the faculty (and couldn't obtain it), the student body or access to necessary funds to proceed along these lines. 70

At this meeting it was aiso expressed that ethnic studies should not substitute for the 'helping programs' but rather an ethnic studies program should complement such programs. The Native Americans and Mexican Americans expressed concern that the present Ethnic Studies Program might jeopardize present monies.

During the Spring of 1970, the Committee on Ethnic Studies sponsored several speakers who represented various ethnic groups on campus.

Minutes of the Committee dated April 2, 1970, indicate that the chairman expressed wishes to be able to 'submit to the faculty by the end of spring term a preliminary report of the Committee's suggestions. Also expressed were ways in which education might explore a means "to literally "take the University" to ethnic minorities. The chairman asked [a Committee member] to bring to the next meeting a resolution to that 
effect." 71

In the minutes of the Committee dated April 12, 1970, the first mention of budget is made. It is important to note that several of the respondents state that it was at this point that political pressures began to come into effect. Respondents reported to the author that the pressures were always present, but never led to any open confrontation. Professor Adams stated, "There is nothing in my files to indicate that this pressure ever existed." Minutes of the meeting indicate other discussions of budgets:

Discussion of budget brought out that the $\$ 10,000$ proposed was for instructional purposes only, that in ail probability there would be required another $\$ 10,000$ for the cost of a director, another $\$ 10,000$ for the cost of the three student assistants plus the cost of staff and an M \& E budget for 1970-71. 12

Minutes dated May 4, 1970, discuss the duties of the Director of the Ethnic Studies Program, including his position as part of the budget:

It was agreed to recommend a full-time director be hired, FTE to be split .50 between administration and active teaching in an Ethnic Studies oriented studies course. The committee was made aware that it may take a year to search for and hire a proper director whose responsibility 73,171 be to plan and organize a curriculum for Etinnic Studies. 73

Later minutes indicate the following:

There still seems to be strong feeling within the committee that more and faster progress would be made with a program of Ethnic Studies if the right director is found and if he would be free to devote 1.00 FTE to organization and promotion of the program for at least the first year.?

On June 1, 1970, the Committee on Ethnic Studies submitted to the Dean of Faculty a proposal for ethnic studies. This proposal contained: (1) the rationale for ethnic studies; (2) the objectives of the program; and (3) the curriculum. 
Several respondents indicated that at this point in time political activities were stepped up and pressures were brought to bear to discredit the Ethnic Studies Program.

Professor Adams: "When the program began, we were aware that there might be political maneuvers brought to bear against the program. We felt this might occur because of the nature of the courses to be offered and the name itself, "Ethnic Studies." But our intentions were made quite clear from the beginning; we were expanding the liberal education program of the University and exposing the entire campus to a broader educational background. In that context the program was not specifically designed to meet the needs of any specific minorities.

"Almost $\$ 20,000$ seed money had also been provided for the Ethnic Studies Program to operate in the coming 1970-71 academic year. Minority interest groups began to apply pressure to the administration, not the faculty. At first this was done through regular bureaucratic channels. Finding that their grievances were not being met, these interest groups went. to the President of the University. The result of this move was that the administration tabled the proposal, thus allowing the students to do two things: (1) review the proposal; and (2) make some amendments to the initial proposal.

"There was no response from the students. This meant that the seed money initially earmarked for Ethnic Studies was about to revert back to the State Board of Higher Education in an incremental fashion, one-ninth of the $\$ 20,000$ per monch. The time did elapse and the complete $\$ 20,000$ reverted back to the State Board of Higher Education.

"Two conflicting points of view persisted: the non-white students felt that they couldn't identify with the stated Ethnic Studies Program 
unless it were offered in isolation, or had autonomy. Our committee, in contrast, supported an expansion of the standard curriculum."

Professor Bales: "The President of the University appointed the Dean of Liberal Arts to act as mediator between the two factions. What happened, however, was that the Dean of Liberal Arts subsequently developed an alternative plan.

"While this was going on, a second committee was formed to investigate the tabled Ethnic Studies Program. Much of the format of the first committee findings was left intact and an additional budget was added, thus bringing the total sum of the proposed budget to $\$ 35,000$. This was later submitted for consideration to the faculty meeting on April 12, 1972.

"The substitute plan that was developed by the Dean of Liberal Arts was also referred to by several respondents as the 'President's Plan.' This plan called for the monies to be used to hire two additional faculty to teach ethnic studies."

Professor Hanes: "When the President's Program was introduced, I, as Chairman of the Committee on Ethnic Studies, began to hear from small factions of minority students who gave me some advice. These students indicated that in the given situation I couldn't possibly make all the factions happy and the best thing I could do was to do what I had to do. By that they meant that I should support the ethnic studies idea."

Professor Adams: "In the beginning the President's Program drew support from minority groups on campus partiy, I think, in an effort to get back at our Committee on Ethnic Studies. But when it became apparent that the President's plan was in reality offering less than what the original Ethnic Studies Program was offering, opinions changed. I'm not 
saying that they were happy with our program, but it was better than what was being offered by the President's plan.

"The President decided to take the proposed action before the general faculty. This took the form of a substitute motion which was to eliminate the present proposal and use another proposed action; that is, the President's Program. At the meeting on Mày 10, 1972, the faculty turned down the President's motion, and voted to accept the proposal of the Committee on Ethnic Studies."

Professor Hanes: "Current status of the program at the University of Oregon is one of optimism on the part of some students, especially those who are in the process of looking for a director. But to me there is a very difficult task in finding a person who can fill all the roles necessary to meet the demands we have built into the position. We need. a super man or woman, in my opinion."

On May 11, 1972, the Emerald carried the story, "Ethnic Studies Program Approved by Faculty":

The new program, the result of two and one-half years of work by various committees, provides for a 30 hour certificate program using mainly existing ethnic related courses. It also provides for a part time director--a position that inspired much debate at Wednesday's meeting [meaning the faculty meeting that voted for ethnic studies]. 75

The certificate program offered by Ethnic Studies at the University of Oregon is in some ways similar to the certificate program offered at Portland State University. In the body of the Ethnic Studies document, Portland State University is mentioned as an institution within the same educational system that offers a certificate program.

It can also be noted that the role of the director of the new Ethnic Studies Program is on a par with that of the director of black studies at Portland State University in that neither has been a full time 
director, but one-half time directors who also teach one to two courses per quarter.

Professor Bales: "What the director will have to do is be a liaison between the various departments concerned. He will have to think of the position as more than just a job. We are looking for someone who will display considerable personal involvement with the program. The director will have to be someone who is always pulling for the program, on as well as off the campus. That isn't going to be an easy task. That's why it is important for the Search Committee for a Chairman to get the right candidate for this position--someone who has the pioneering spirit."

Professor Adams: "A good part of the $\$ 35,000$ will go into developing three new courses, Ethnic Studies 101, 102, and 103, which wi11 probably be taught by the Director of Ethnic Studies."

Course descriptions of the three prospective courses to be offered by Ethnic Studies are:

ES 101 Ethnic Groups in American Society - 1. Introduction to minority societies, their social, political and religious (or world view) impact on American society and their relationship to the mainstream of American society. This course briefly surveys the history of minority groups, including their contribution to American society as well as the forces within American society that have restricted and molded the minority communities.

ES 102 Ethnic Groups in American Society - 2. Taught as seminar sections. A close inspection of particular minority groups (each section to focus on a different group: Black, Chicano, Native American, East Asian, South Asian, or other as appropriate). Each section studies social, political and economic positions of the particular group in recent times. Prerequisite: ES 101. 
ES 103 Ethnic Groups and the American Experience Contemporary impact of American society on minority groups and the forces within American society and the various minority groups working toward change. The course attempts to isolate the various social and political trends currently operating in our society. Prerequisite: 101-102.76

In addition to the above it should be noted that the proposal for an ethnic studies program calls for the offering of sixty-six additional courses in seven other disciplines within the University structure (Appendix C). 


\section{CHAPTER VI}

\section{ANALYSIS OF THE DATA FROM THE FOUR CASE STUDIES AND GENERAL INTERPRETATION}

In the previous chapter there was an effort to describe the sequence of events which led to the establishment of black studies programs or courses on each of four campuses, Reed College, Linfield College, Portland State University and the University of Oregon. In this chapter there is the effort to analyze and interpret these data, with special emphasis on the periods of conflict experienced by the faculty, administrators, and students.

\section{REED COLLEGE: ANALYSIS}

The precipitating events which inaugurated the movement to estabTish a black studies program included:

(1) The establishment of a black student union. The BSU acted as the focal point for protest. The BSU also developed a unity among the black students that was both formal and informal.

(2) The high quality of the students involved, and their ability to estimate successfully the behavior of the college in a given crisis. In talking with the faculty and a student who were involved in the developmental process of black studies, it became clear that BSU nembers were rather certain how the faculty would react to given actions of the BSU.

The members of the BSU, both male and female, were perceived to be strong personalities. As a result of this, members of the Reed BSU were capable of leadership as well as implementation of agreed-upon plans. The age of the black students involved in the developmental process of 
biack studies at Reed College was higher than for other students. One respondent emphasized the advantages of "real world experiences" of black students in the promotion of black studies at Reed College.

(3) Another factor was the ability of the Reed BSU to establish lines of communication with other colleges and universities which were involved in similar struggles for black studies. This provided alternative methods of approaching problems necessary in acquiring a black studies program.

(4) The turning point in favor of black studies occurred when the BSU occupied ETiot HalT, bringing all the business operations to a halt. This challenge to the college brought the issue of a black studies department to the attention of 211 on campus. A number of informants bel ieved that had this protest act not occurred, there probably would not have been a black studies department at Reed College.

(5) The occupation of Eliot Hall was followed by discussion between members of the faculty and students in which several points were clarified. One was the sincerity of the students, in which it was learned that the occupation of Eliot Hall was only a symptom of the deeper concern of the BSU, and that the present crisis wasn't going to go away. Another was the advantage of communication based not on a studentprofessor relationship, but on a perşon-to-person relationship, void of titles. This relationship proved rewarding in some cases, although not in all.

(6) Of key importance to the developmental process at Reed College was the unmeasured characteristic referred to as liberal image. Involved in this liberal image is a variety of themes, especially ability to reason one's way through problem situations and ability to develop 
rational solutions that will be agreeable to both groups. This 7 iberal image also extended into the personal relationships, and dealt with a concept of how blacks should be responded to. In the opinion of the author, Reed College more than any of the other colleges in the survey could be characterized as having "rational men" seeking a solution to what may be identified as a "rational problem." Black students knew of, and took advantage of, this image. Many subtle hints on the part of the respondents suggest that indeed this was the case. One respondent, who had occupied Eliot Hall, when asked by the author if he or any members of the BSU were coricerned, or worried about the fact that it was possible for the President of the College to have them physically removed by the police, paused and then queried, ". . . and hurt their liberal image?"

\section{Academic Structure of the Institution}

Reed College is a private college, presided over by a board of trustees. Reed's academic structure is not marked by a high degree of bureaucratic structure. At Reed the principal decisions concerning academic policy are put to a vote of the faculty. Because of the lack of bureaucratic structure, academic decisions concerning the folicy of the College can be made quickly, and in a decisive manner. This structure has advantages as well as disadvantages for black studies.

The lack of a highly formalized procedure means that a prospective program can be introduced into the academic structure in a relatively short period of time.

The disadvantage is that a program may be voted out in a similar manner. This type of structure, therefore, lends itself to informal 
agreements, collusions, and other arrangements that can erode any given program. Hence, social political maneuvering can be very important. Location of the Campus

Reed College is located in the Portland Standard Metropolitan Area, where 22,000 of the state's 28,000 blacks reside. However, Reed is located in southeast Portland, several miles from the concentration of the black population. The relatively high cost of attending Reed and living in the vicinity suggest that it is unlikely that the Reed student body will soon have a sizeable number of minority students.

Current Status of Black Studies

At present Reed College has a black studies program, and three faculty who teach one or more classes related to the Black Experience. The future of the black studies program at Reed College is questionable for several reasons: (1) The increasing fragmentation of the BSU, which formerly served as a protector; (2) The control of admissions policies by the faculty, which the BSU never controlled or influenced; (3) The lack of protection for an autonomous structure in a highly non-bureaucratic structure; and (4) Reed College has recently begun to suffer financial difficulties; if this persists, an expensive program such as black studies is vulnerable. 
Figure 1

Type of Structural Change at Reed College

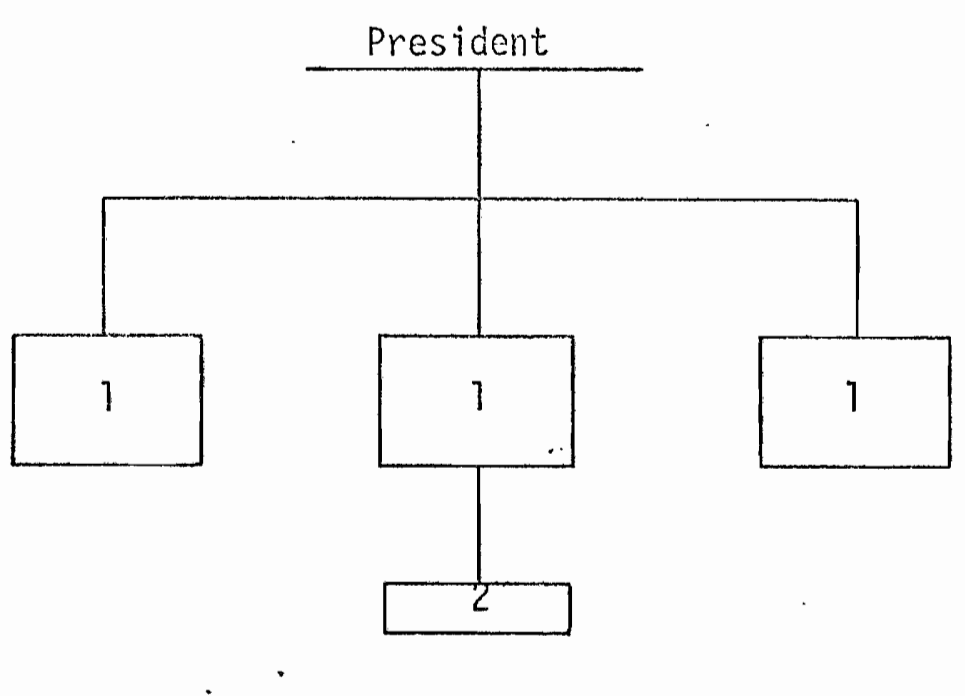

Before Black Studies:

1. Vice-Presidents

2. Dean of Students

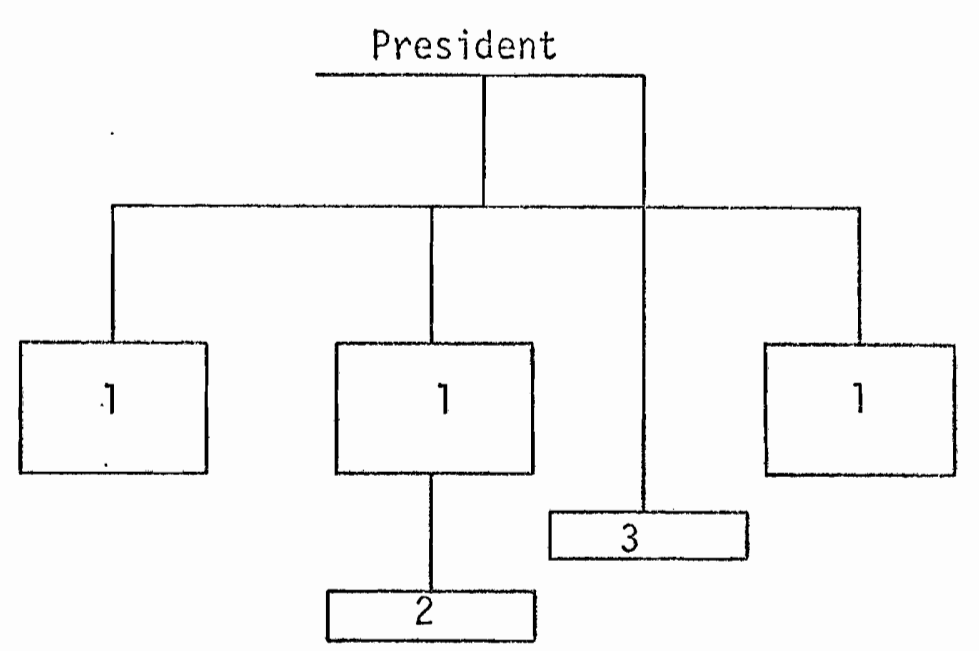

After Black Studies:

1. Vice-Presidents

2. Dean of Students

3. Director of Black Studies Department 


\section{LINFIELD COLLEGE: ANALYSIS}

The precipitating events necessary to promote black studies at Linfield College have not yet fully developed. During the developmental process of black studies; Linfield College had entered into a period of financial exigency, in which the survival of the College itself was of prime concern.

Within this framework there did develop an Action Committee which was successful in gaining, on paper, several concessions from the administration. However, funds to implement these concessions were not available. This was stated by one respondent to be of common knowledge. If this was the case, then it might explain the stated lack of enthusiasm on the part of most black students on campus.

It seems clear that if faculty are given a choice, in a period of financial exigency, of how Linfield's finances are to be allocated, the predictable choice would be to maintain those courses that are considered paramount to the College.

Recently there have been several exciting developments at Linfield: (1) The financial climate is starting to change in favor of Linfield College; (2) The present number of black students on Linfield's campus (twenty-five) is projected by one of the assistant deans of the college to increase to one hundred or more by 1974-75. Given the location of the campus, the increasing number of black students, and no non-white faculty, Linfield College appears to be at the beginning of the developmental stage. 


\section{PORTLAND STATE UNIVERSITY: ANALYSIS}

The precipitating events which helped to bring about the promotion of biack studies include: (1) The state Chancellor's giving permission for Portland State University to explore a program by which the educational structure could be modified to include more minority students; (2) The President's assigning a task force to expiore the manner in which additional minority students could be admitted; (3) The appointing of the Black Studies Sub-Committee and subsequently, the Black Studies Council; and (4) The interaction of the Black Student Union and the faculty of Portland State University. The BSU at Portland State was not responsible for the initial change, but was responsible, in part,. for the eventual direction of change. This process produced occasional conflict, especialily between the BSU and the Portland State faculty. The BSU wanted recognition in the form of being able to participate in decisions that would shape the fucure of the black student at Portland State University. The faculty initially preferred to retain these prerogatives for itself.

The ESU reportedly engaged in violence of two kinds: (1) overt, where persons were physically attacked by other persons, and (2) verbal altercations. Portland State University was not marked by a high degree of overt violence; only two cases were reported by respondents. However, verbal altercations were reported to have occurred quite often. The significance of these verbal altercations was that they often involved persons that could, and on previous occasions were reported to have, become overtly violent. Hence, there was no assurance that the verbal a) tercations would not end in overt violence. 
The leadership of the BSU consisted of eight members. However, one question that the administration, faculty, and staff were unable to determine, in retrospect, was how significant an influence the BSU core members had on the body of the BSU membership in terms of any actions of a mass nature.

\section{Academic Structure of the Institution}

The structure is important to developmental processes of a black studies center. There is supposedly a policy with the State Board of Higher Education, in which it does not duplicate schools within its structure. The same is said to be true of new programs. If a course was not offered at a desired institution, the individual would be referred to the state institution that offered the course, rather than duplicate the same course in another of its educational institutions. Since Portland State University has a Black Studies Center, it is not likely to be duplicated. While the bureaucratic structure of Oregon's stateoperated schools is incremental in orientation and slow in response to outside pressures for change, it is this same structure that can act to protect a program once within the academic structure. Generally speaking, while collusion and other informal agreements are possible in a bureaucratic structure, these agreements are usually enacted through the bureaucratic procedure. This process allows for the opportunity for department officials to respond to specific changes or modification that might be in the best interest of the department concerned.

of paramount importance to any program is a director who has a working knowledge of the system of which his program is a part. Equality important, it appears, are the person's academic credentials. It was 
expressed by several respondents that the former director did a good job establishing the Black Studies Center, but he had only a master's degree. This was clarified by the respondents' stating that the individual's status reflected the status of the program. Since most department heads at Portland State University are Ph.D.'s, it was stated that other department heads would have been more receptive to the director if he was a Ph.D.

\section{Location of the Campus}

The Tocation of Portland State University is of prime importance to the current "successful" development of the Black Studies Center. The location and the distribution of the population in favor of blacks in general makes it logistically, financially and politically justifiable to the State Board of Higher Education that Portland State University is the proper location for the Black Studies Center. Also related to the developmental process is the location of the institution in terms of implementing stated policies. Portland State has a relatively better opportunity than other institutions in this survey to legitimize its existence within the academic structure, predicated upon what it does within both the adjacent black community and the academic community.

\section{Current Status of Black Studies}

The future of the Black Studies Center looks optimistic for several reasons: (1) It would not be a politically expedient move to dissolve the Black Studies Center at this time; (2) The location of Portland State University is conducive to exploring the Black Experience; (3) The administration has just hired a black director who has a Ph.D. to administer 
Figure 2

Type of Structural Change at Portland State University
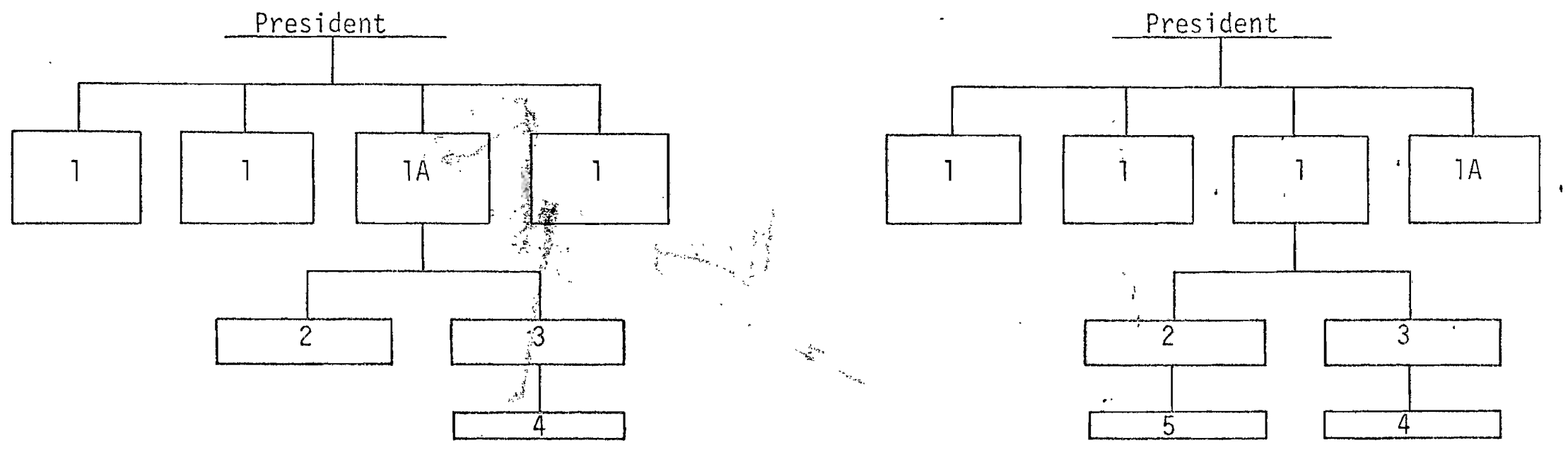

Before Black Studies:

After Black Studies:

1. Vice Presidents

1A. Vice President for Academic Affairs

2. Dean of Undergraduate Study

3. Dean of the Social Sciences

4. Departmental Leve 1: Sociology, Psychology, History, Anthropology
1. Vice Presidents
1A. Vice President for Academic Affairs
2. Dean of Undergraduate Studies
3. Dean of the Social Sciences
4. Department Leve1: Sociology, Psychology History, Anthropology
5. Director of Black Studies 
the program, giving the program the necessary academic position for bargaining with other departments on an equal basis.

\section{THE UNIVERSITY OF OREGON: ANALYSIS}

The precipitating events which contributed to development of an ethnic studies program include: (1) the President's appointing a committee to investigate the possibility of expanding the current academic curriculum to include the experience of minority groups; (2) the research conducted by the committee, which culminated in a written proposal; (3) the conflict that developed between the faculty and political interest groups on campus; and (4) the faculty!s voting against the President's plan of action.

The support for an ethnic studies program had more plausibility at the University than a specific minority program, i.e., black studies. As previously noted, the 1970 Census lists Eugene has having 2,353 minority residents. These are almost equally divided among blacks, American Indians, Oriental Americans, and "Other" minorities. There is also a sizeable Mexican American population in the Eugene area. A11 of these are the potential beneficiaries of an ethnic studies program. One comprehensive program may also el iminate the need to respond continually to new and shifting minority group interests. Finally, given present financial conditions of operating budget the State Board of Higher Education is allotting to its various institutions, ethnic studies is an economically expedient move at this time.

A major feature of the process at the University of Oregon was that there was no reported overt violence at any stage of the development of the Ethnic Studies Program. 


\section{Academic Structure of the Institution}

A strong bureaucratic structure at the University of Oregon was important in determining the outcome of the Ethnic Studies Program. This is in spite of the strong internai pressures exerted by political interest groups on campus, pressures which were strong enough to table the motion for ethnic studies for nine months. Had this pressure been exerted in an institution with weaker bureaucratic structure, it may have been sufficient to bring about an institutional change more to the liking of the pressure groups concerned. This was not the case.

\section{Location of the Campus}

Location and distribution of the minority population in the Eugene, Oregon, area could not justify the establishment of a program for a single ethnic group. The distribution of the minority population in Eugene is relatively even, thus making the move for a single, multiethnic program more feasible economicaily. The University has successfully demonstrated to the State Board of Higher Education, which is in charge of the allocation of funds, the feasibility of this plan.

\section{Current Status of Ethnic Studies Program}

At present (July, 1972) the proposal is being considered by the State Board of Higher Education. The Search Committee at the University of Oregon is in the process of looking at prospective applicants and considering them for candidacy to the program that is to be initiated in the Fall of 1972 .

Informal interviews with several minority students on the University of Oregon campus sought to ascertain their assessments of the pro- 
posed ethnic studies program. There seems to be among many of the minority students an attjtude which can best be characterized as indifferent--"It won't affect my thing at all." The general opinion is that the Administration and faculty have dore something to the student body, not something for the student body.

\section{THE ROLE OF BLACK STUDIES IN REDESIGNING ACADEMIC STRUCTURES}

A major theme that runs throughout the literature on the developmental process of black studies is conflict. The origin of the conflict has been seen as national in scope. The conflict became intensified in the mid-1960's as major agencies of the black movement, especially the Student Non-violent Coordinating Committee (SNCC), and the Congress of Racial Equality (CORE) moved from advocacy of civil rights, which, during the previous decade or so had been the major thrust of the black movement, to a new thrust, which called for black power. The new direction was also accompanied by a serjes of cultural redefinitions. One of these redefinitions involved the self image of the Black American. The new self image consisted of many facets, one of which was to gain control of one's own destiny. This position became articulated when a small but vocal minority of blacks moved to the forefront of the news media, e.g., Malcolm X, Stokely Carmichael, and subsequently the Black Panther Party.

As the redefinition began to unfold, new issues came to the fore. One of the new issues was that of community control. Community control was advanced as a base for the development of power. As black communities became interested in the concept of conmunity control, as expounded by ivilcolm X, Stokely Carmichael, and the Black Panther Party, they discovered that community control required an analysis of those political, 
Economic, and social forces that affected a community. A growing recognition of the need to acquire skills necessary to analyze those forces has led blacks to turn to higher education, especially in the social sciences. Of paramount importance to black college students is the effort to protect their recently redefined self image (Black Consciousness). In so doing, the students risk antagonizing traditionalist professors to such an extent that overt conflict may eventuate.

Most black students who attended college before the emergence of the biack studies movement were from the black middle class, or were poor but gifted blacks who had, typically, middle-class aspirations. These students often provided the only model of black behavior many white professors experienced. These students moved through higher education in a quite orderly, but compromising manner; if statements about race in a particular academic discipline were known to be inaccurate or inadequate by black students, which was frequently the case, the statements likely went unchallenged by those students.

Educators watched the redefinition process as individuals began to refer to themselves as black, and gradualiy the news media began to use the term "black man" and "black woman" instead of "Negro." But a strong sense of déjà vu seemed to pervade the vision of educators. Many social scientists had watched similar redefinition processes of black Americans. This change covers a wide variety of terms used to describe the black man. Among the more recent terms are Negro, Afro-American, and black. In previous redefinitions there were typically no significant behavioral changes. Why would the term "black" and its accompanying definitions be any different? 
The data suggest that higher education stayed woefully unaware of the redefined self inage of the biack student, especially of the behavior that the new set of meanings called for. Higher education continued to communicate and relate to the black student using the former set of references, Afro-American, and Negro, which were perceived in negative terms. Inability of educators to recognize the emerging definitions did not produce overt conflict immediately, but did nurture a hidden antagonism on the part of black students. This helped to sharpen the image of higher education as an out group (enemy).

Especially in the setting of the classroom, in the white professorblack student relationships, incipient conflict emerged. The professor, including the 1 iberal, was seen as naive, or ignorant, or even racist, by the new black student, as he sought roots in the very blackness that the university disavowed:

At the same time, the black student remained aware of the significance of the knowledge the white professor had in his possession, knowledge which could contribute both to enlightenment and to success for blacks.

The challenge has become that of developing a means by which the black student can simultaneously seek his sustenance in a heritage of "blackness" and nurture his hope in knowledge which has traditionally been associated with "whiteness."

\section{THE ROLE OF FACULTY COUNSELORS}

While black students were receiving counseling from sources that were external to educational institutions, there was still a lack of 
information as to how specific individuats and the given educationai structure itself would respond to demands for implementation. This knowledge was unique to the educational institution concerned, and depended upon its structure and other internal as well as external variabies.

Once into the developmental process of black studies the various perspectives of participants took on new meaning. The demands of black students were often perceived as unrealistic by faculty and administrative staff; faculty and staff, in some cases, made offers that they could not implement; blacks sometimes misunderstood the motives of professors. What could each interest group realistically expect from the other, given the misunderstandings and suspicions?

During the developmental process black students needed assistance in assessing the capabitities of university personnel to fulfill promises made. This assistance could be best provided by individuals within the academic structures concerned. In all four cases of this study, at least one white academician on each campus served as internal counselor to BSU's or minority interest groups. Their knowledge of the academic structure in question and individuals making various offers allowed them to make objective analysis as to what could be realistically expected from the academic system in question. As internal counselors rather than actual negotiators, they did not become overtly involved in conflict itself. In all cases these individuals were sought by the black students because of former relations and because the black students felt they could be trusted.

There are some general characteristics that all four persons seem to have in common: (1) All of the members were middle-aged (in their 
forties); (2) They all held positions of influence within the academic structure; (3) All, as a result of the redefinition process of biacks, had had experiences favorable and unfavorable, with black students; they had noted recent changes in the behavior of black students but were not quite sure what the difference was; (4) All were somewhat introverted, observant, and self-confident; and (5) None had a vested academic interest such as, for example, a sociologist of race relations may have.

There was frequent mention of young educators who were very helpful to the black students and the movement towards black or ethnic studies. The typical culmination of such a report was, however, "But he didn't get tenure." The clear indication was that their participation was the key factor in the denial of tenure. In contrast, the middle-aged professors had previously established positions and power bases, and they remained within the academic structure. The difference seemed to be not whether one had tenure, but the manner in which a professor became involved, that is, whether as a counselor or as an activist. Successful involvement was associated with ability to maintain respect of both interest groups (faculty and students). The faculty generally respected the counselors for their academic achievements and other previous accomplishments. The black students respected the same persons for their successful personal relationships with black students. 
CHAPTER VII

\section{CONCLUSIONS}

The number of case studies for this project was limited to only four. Limited time and resources have made it difficult to provide a thorough reconstruction of the process on each campus by which black studies in one form or another was adopted. More broadiy, the movements to establish black studies programs on campuses nationwide are so recent, and their impact on higher education so dimly perceived, that it is premature to attempt bold generalizations at this time.

However, this thesis, the author believes, has captured and preserved a small slice of a development in American higher education that has aiready had significant impact on the nature of the university, with the prospect that greater impact--on curriculum, on standards, on faculty recruitment, on the accepted nature of knowledge--is yet to come.

An apparently new awareness by minorities has led to a challenge to the traditional patterns of higher education. Minority students have successfully challenged "sacred" rules. White faculty have been called upon to learn new perspectives, to yield power, to relate to students in dramatically new ways. This challenge has resulted in the hasty establishment of black studies courses or programs on many campuses. The outcome is, of course, not yet known.

Black studies has been justified on the grounds that the Black Experience has been significantly left out of the curriculum in American higher education. The demand for separate departments, for black faculty only to teach black students, for enphasis on black history and black 
iicerature and biack social science, has produced in higher education an eiciich which apparenty is new. Previousiy, different views of history may be in competition, but now, mutually exclusive views of history are to be tolerated, without exchange.

It is too early to predict if, and when, a new synthesis, that is, the return of competing histories which incorporate the Black Experience, will occur. In the meantime, there is need to consider the consequences of black studies for black students and for the university now.

What was supposed to have taken place in the developmental process was the synthesis between the two perspectives: black studies and white studies. However, this, as of the present, has not happened. A reevaluation of black studies by its student designers is now under way. These designers often reside in the low income area, and have influence on younger black students attending college and universities. Some have younger brothers and sisters, or friends, who are for the first time attending institutions of higher education. These younger black students have noted that respected black leaders involved in the development of black studies have themselves been coopted into the traditional bureaucracy of higher education, and are not necessarily working for the best interests of black students. Black studies is perceived in part to be responsible for this corruption. Hence, incoming black freshmen often approach the new program with an element of caution.

There is a second theme that has contributed to the present apprehension of black students about black studies. Unfortunately the impact is not known at this time. For several years black political newspapers, The Black Panther Paper and Mohammad Speaks; for example, plus a host of 
community newspapers, have been very skeptical of all higher education. Mohaminad Speaks states flatly that higher education refuses to teach the biack man about his heritage. The present state of black studies is perceived by the above publications to be in a defunct state. This substantiates their earlier contentions that higher education is inadequate and unreceptive in responding to the educational needs of black people.

In the late 1950's when black scholars, community organizers, and militant students began to participate in the redefinition process of the Black Experience, standard definitions of black people and their experience in America took on new perspectives. This, of course, was not the first such movement for a redefinition of the Black Experience. In the 1920's, for example, Marcus Garvey sought to promote ethnic consciousness among blacks. But it was only in the 1960's that black scholars began to be perceived by the entire scholarly worid as authorities on black people.

At this period in time it became possible for the redefinition to have a base in the academic setting. Blacks had an opportunity for the first time to define their characteristic group experience in America. The conference in Washington, D. C., in November, 1968, is an example of taking advantage of this opportunity. Thus, black studies made its entrance into higher education.

However, once within the system of higher education, black studies had to contend with structural and organizational problems that face many new departments and programs. Of foremost importance is the conversion of "Tegal" approval into full "legitimation" within academe. This entails maintaining power in hiring, in curriculum, and similar matters on route to 
legitimation.

After apparently prosperous beginnings the current status of many black studies programs is slowed or severely retarded; most must alter their present status in order to survive.

This change calls for a shift from unclear and unspecified goals to more specific and measurable goals. This change has become necessary for a variety of reasons but most immediate, and notable are financial reasons, which have forced a reevaluation of many of the newer academic pursuits. It appears that established academic disciplines can withstand moderate financial pressures because they have long established sources of enrollment and power to protect their interests. This is not true of biack studies. Newer programs are often among the smallest in budgetary allotments, faculty and staff, and more likely to be among those first to be cut from the academic budget.

The feasibility of abolishing a black studies program would depend upon several factors: (1) organized interest groups on campus pressuring for change, i.e., BSU, SDS, and Third World Organizations; (2) recruiting practices; (3) structure of the institution, public or private; and (4) the size and militancy of a nearby black community.

On those campuses where it may not be politically expedient to abolish a black studies program, arrangements other than those currently operative will likely have to be made. "Politically expedient" refers to the consideration of repercussions that might accompany the attempted removal of black studies programs and departments, as well as consideration of the institution's long-range plans for development and growth. 
In the opinion of the author, we can expect black studies to be challenged within the near future. If this is correct, and the challenge is successful, then there will be a redefinition of the present,goals and aims of the black studies programs and departments.

Of course, as our four cases suggest, local circumstances--the type of college, the size of the black community, etc.--have a great bearing on the form and the vuinerability of black studies programs. However, several general predictions appear to be in order.

It certainly appears that increasing percentages of blacks are likely to be recruited to faculty positions. New university awareness, civil rights pressures, increasing availability of doctoral candidates for hiring, a11 suggest this. Likewise, most campuses can anticipate increasing percentages of minority students, with or without special inciucements.

What is then at issue is the future form of black studies. Are the continuation of a separate department, a separate curriculum, special racial qualifications for hiring, politically feasible? Academically sound? Economically justifiable?

Although the evidence to date is quite meager, it appears that younger black students may not be black studies zealots; increasingly black professors are likely to want their anchor in an established discipline and not in a program dependent upon ethnic jdentity. If this is so, then the existing black studies programs will have to adapt to survive.

There are several new roles which black studies may play, apart from direct instruction of blacks. One role is research. The black studies movement itself has highlighted the dearth of scholarly information about blacks. In addition, the continuing needs of blacks in over- 
coming the deprivations of past generations call for continuing research and program ckatuation.

Another possibility is the role of advocate. There continues to be considerable controversy over the political role of the university, but both professors and students appear to be increasingly issue oriented--witness civil rights and peace concerns, ecological interests, applied programs of many sorts. The role of advocate for minority interests may find a haven in the future university.

Another possibility is for a redirection toward concern for longrange goals of the whole society. A so-called "melting pot" society has many unresolved philosophical issues. Is cultural pluralism to be protected? Is complete assimilation the proper goal for American society? Is the goal of America to obliterate all distinctions among peoples, or to protect the right to be distinctive?

In short, what is the proper relationship of blacks and other minorities to the total society?

These questions are closely tied to public policy. For instance, current debates over school busing, over the rights of the Amish to violate compulsory school attendance 7 aws, over teaching English as a second language, over strategies to integrate neighborhoods, very much need the attention of researchers and scholars.

And, there will be for years to come white students who are woefully ignorant of the Black Experience. There may be, after all, a continuing instructional role for a black studies program. 


\section{REFERENCES}

1. Healy, Alex and Malcolm X, Autobiography of Malcolm X. New York: Grove Press, 1964.

2. Cleaver, Eldridge. Soul on Ice. New York: Dell Publishing Co., Inc., 1968 .

3. Harding, Vincent. "The Future of Black Studies," in Kerry Smith, ed., Current Issues in Higher Education. Washington D.C.:

American Association for Higher Education, 1970. pp. 212-213.

4. McEachern, Gaye. "Afro-American History: Schools Rush to Get in Step." Nations Schools. Vol. 82, No. 3 (1968), 58-62.

5. Bander, Edward J., ed. Turmoil on the Campus. New York: H. W. Wilson, 1970. p. 146 .

6. Todd, Furniss W. "Black Studies Programs and Civil Rights

Violations." A Special Report to the American Council on

Education. Washington V.C.: (19/0). p. 3 .

7. Hare, Nathan. "A Radical Perspective on Social Science Curricula," in Armstead L. Robinson, Craig C. Foster and Donald H. Oglivie, eds., Black Studies in the University: A Symposium. New Haven, Connecticut: Yale university Press, 1969. pp. 204-221.

8. Scranton, William $W$. The Report of the President's Commission on Campus Unrest. Washington D.C.: Superintendent of Documents, United States Government Printing Office, 1970. p. 20.

9. Ibid.

10. Ibid.

11. Grant, Joanne, ed. Black Protest: History, Documents and Analys is 1619 to Present. New York: Fawcett, 1968. pp. 426-432.

12. Scranton, op. cit., p. 22.

13. Smith, Kerry. "The Troubled Campus." Current Issues in Higher Education. Washington D.C.: American Association for Higher Education, 1970. p. ix.

14. Blausteen, Albert P. and Robert L. Zangrando, eds. Civil Rights and the American Negro. New York: Trident Press, 1968. p. 591.

15. Gallagher, Bue17, G., ed. College and the Black Student: NAACP Tract for the Times. New York: National Association for the Advancement of Colored Peopie, 1971. p. 17. 
16. Iliti., p. 11 .

17. Filor, Pall A. "Survey of BTack Studies: Position and Opinions." Eucational Leadership. Vo1. 28, No. 4 (January, 1971), pp. 369372 .

18. Danie1s, Halter. "Black Studies in American Education." Journal of Negro Education. Vol. 39, No. 3 (1970), pp. 189.

19. Deer, Herman. "What Does the Innocent Teacher Impart as History?" Journal of Negro History. Vo1. XXV, No. 4 (1940), pp. 474-84.

20. Hamilton, Charles V. "The Challenge of Black Studies." Speech delivered at the Institute of Airo-Americans, New York University, 1970. Mimeographed. See also College Management, Aug., 1971, p. 39.

21. Dariels, op. cit., p. 190.

22. Ibid., p. 191.

23. Smith, William. "The Black Studies Graduate in the Real World." Personnel and Guidance Journal. Vol. 48, No. 9 (May, 1970). pp. 767-69.

24. Rosser, James and Henry Wilson. "Black Studies: The S.I.U. Approach." Southern Ill ino is University Alumni News. Carbonda Te, Illinois, 1970. p. 8 .

25. Cruse, Harold. "The Integrationist Ethic as a Basis for Scholarly Endeavors," in Robinson, et. a1., eds., Black Studies in the University: A Symposium. NeW Haven: Yale University Press, 1969. p. 10.

26. Poussant, Alvin. "The Role of Education in Providing a Basis for Honest Self-Identification." Black Studies in the University: A Symposium. Ibid., pp. 194-201

27. Lewis, Arthur W. "The Road to the Top is through Education Not Black Studies." New York Times Magazine. (May 11, 1969), pp. 40 .

28. Hare, op. cit., p. 105.

29. Bander, op. cit., p. 147.

30. Ibid., p. 148.

31. Skolnick, Jerome. ed. The Politics of Protest: Violent Aspects of Protest and Confrontation. Wasilington D:C.: Supertintendent of Documents, United States Government Printing office, 1970. 
32. Scranton, op. cit.

33. Valentine, Charles. Black Studies and Anthropology: Scholarly and Political Interests in Afro-American Culture. Redding, Mass.: Addison-Wesley, 1972.

34. Skolnick, op. cit., p. xxiti.

35. Bander, op. cit., p. 135.

36. Skolnick, op. cit., p. xxiii.

37. Scranton, op. cit., p. 535.

38. Valentine, op. cit., p. 21.

39. Black Studies at Reed: A Review, (December 16, 1968). p. 2. (Papers made avajlable to the author by the Dean of Mathematics at Reed College.)

40. From information available at Portiand State University in the Educational Activities files under the heading, "Black Studies."

41. Black Studies at Reed: A Review. op. cit., p. 1.

42. Ibid., p. 2.

43. Ibid., p. 3.

44. Ibid.

45. Ibid., p. 4.

46. Ibid.

47. Ibid.

48. Ibid., p. 5.

49. Ibid.

50. Ibid., p. 7.

51. Ibid.

52. Ibid., p. 9.

53. Ibid., p. 10.

54. Ibid., p. 11.

55. Ibid., p. 12. 
56. Ibid., p. 13.

57. Ibid., p. 12.

58. Ibid.

59. Minutes of the Faculty lleeting, Linfield College, McMinnville, Oregon, Sept., 2, 1968. p. T.

60. Ibid., p. 6

61. "A Communication to Perspective Black Students by Black Students," Linfield College, Mclinnville, Oregon, 1970-1971 academic year, p. 1 .

62. McLaurin, Philip. "Has Success Killed the B.S.U.?" Unpublished paper, Portland State University Black Studies Department (Feb. 1971). p. 1.

63. Ibid.

64. Ibid.

65. Minutes of the Black Studies Council, Portland State University, Portland, Oregon, Jan. 10, 1969, p. 1.

66. Ibid., February.18, 1969, p. 1.

57. Ibid.

68. Oregon Daily Emerald, an independent student newspaper, University of Oregon, Eugene, May 22, 1968.

69. Minutes of the Committee on Ethnic Studies, University of Oregon, Eugene, Feb. 19, 1970.

70. Ibid., March 5, 1970.

71. Ibid., April 2, 1970.

72. Ibid., Aprit 16, 1970.

73. Ibid., Apri1 14, 1970.

74. Ibid.

75. Oregon Daily Emerald, May 11, 1972. op cit.

76. From "A. Proposed Ethnic Studies Program at the University of Oregon." Presented to the University of Oregon Faculty. James R. K1onoski, Chairman. Mimeographed Apri1 12, 1972, pp. 69-70. 


\section{A SELECTED BIBLIOGRAPHY}

Bander, Edward J., ed. Turmioil on the Campus. New York: H. W. Wilson, 1970.

BTausteen, Aibert P. and Robert L. Zangrando, eds. Civil Rights and the American Negro. New York: "Trident Press, 1968.

Bracey, John H., Meier, August, and Elliott Rudwick, eds. Conflict And Competition: Studies in the Recent Biack Protest Movement. Belmont, California: ladsworth, 1970.

Brimmer, Andrew F. "Education and Economic Opportunity." In Rustin, Bayard, ed., Black Studies: Myths and Realities. New York:

A Philip Randolph Fund, 1969.

Carmichaei, Stokely and Charles Hamilton. Black Power. New York: Vintage Books, 1967.

Cleaver, Eldridge. Soul on Ice. New York: Dell Publishing Co., 1968.

Coser, Lewis A. The Functions of Social Conflict. New York: Free Press, 1956.

Cruse; Harold. "The Integrationist Ethic as a Basis for Scholarly Endeavors," in Robinson, et. al., eds., Black Studies in the University: A Symposium. New Haven: Yâle University Press, 7969.

Daniels, Walter. "Black Studies in American Education." Journal of Negro Education. Voi. 39, No. 3 (1970), 189-91.

Deer, Herman. "What Does the Innocent Teacher. Impart as History?" Journal of Negro History. Vo1. XXV, No. 4 (1940), 474-83!

Draper, Theodore, The Rediscovery of BTack Nationalism. New York: Viking Press, 1970.

Drimmer, Melvin. "Teaching Black History in America: What are the Problems?' Journal of Negro Education. Vol. 38, No. 4 (FalT, 1970), 440-446.

Foster, Julian and Durward Long, eds. Protest: Student Activism In America. New York: William Morrow, 1970.

Fuller, Paul A. "Survey of Black Studies: Position and Opinions." Educational Leadership. Vo1. 23, No. 4 (January, 1971), 369372. 
Galiagher, Buell, G., ed. College and the Black Student: NAACP Tract for the Timies. New York: National Association for the Advancement of coiored Peopie, 1971.

Grant, Joanne, edi. Black Protest: History, Documents and Analysis 1619 to Prosent. New York: Fawcett, 1968.

Hamilton, Charies V. "The Chailenge of Black Studies." Speech delivered at the Institute of Afro-Americans, New York University, 1970. Mimeographed. See also College Management, Aug., 1971, p. 39.

Harding, Vincent. "The Future of Black Studies," in Kerry Smith, ed., Current Issues in Higher Education. Washington, C.D." American Association for higher Education.

Hare, Nathan. "A Radical Perspective on Social Science Curricula," in Armstead L. Robinson, Craig C. Foster and Donald H. Oglivie, eds., Black Studies in the University: A Symposium. New Haven, Connecticut: YaTe University Press, 1969. pp. 204-221.

"What Black Studies Means to a Black Scholar." College and University Business. Vol. 48 (May, 1970). 56-60.

"The Battle for Black Studies." The Black Scholar. (May, 1972). $39-47$.

Healey, Alex and Malcolm X. The Autobiography of Malcolm X. New York: Grove Press, 1964.

Hensche1, Annie Marie and Richard Herische1. "Black Studies Programs: Promise and Pitfa]ls." Journal of Negro Education. Vot. 38, No. 4 (Fall, 1969), 423-429.

Lewis, Arthur W. "The Road to the Top is Through Education - Not Black Studies." New York Times Magazine. (May 11, 1969), $35-54$.

Marx, Gary T. ed., Racial Conflict: Tension and Change in American Society. Boston: Lictle Erown, 1971.

MicEachern, Gaye. "Afro-American History: Schools Rush to Get in Step." Nation Schools. Vo7. 82, No. 3 (1968), 58-62.

McLarin, Philip. "Has Success Killed the B.S.U.?" Unpublished paper Portland State University Black Studies Department (Feb. 1971).

Merton, Robert K. "Insiders and Outsiders: An Essay in the Sociology of Knowledge." Address given at the Centennial Symposium of Loyola University, Chicago (1971).

Meyers, Michael. "Black Separation at Antioch: A Retrospective View." American Civil Liberties $\# 227,($ ApriT, 1971). 
Patterson, Orlando, "Rethinking Black History." Harvard Educational Roview. Vo1. 41, No. 3 (August, 1971) 297-375.

Poussant, Alvin. "The Role of Education in Providing a Basis for Honest Self-Identification." In Robinson, et. al., eds. Black Studies in the University: A Symposium. New Haven: Yale University Press, 1969.

Record, C. Wilson. "Some Implications of the Black Studies Movement for Higher Education in the 1970's." To be presented to Division $G$. American Educational Research Association Annual Meeting, New Orleans, Louisiana, February-March, 1973.

Rist, Ray C. "Black Staff, Black Studies and White Universities: A Study in Contradictions." Journal of Higher Education. Vo1. 56, No. 8 (November, 1970), 618-629.

Robinson, Armstead, Craig Foster, and Donald Oglivie. eds., Black Studies in the University: A Symposium. New Haven: YaTe University Press, 1969.

Rosser, James and Henry Wilson, "Black Studies: The S.I.U. Approach." Southern Ill inois University Alumni News. Carbondale, Illinois, 1970 .

Scranton, William W. The Report of the President's Commission on Campus Unrest. Wasiington, D.C.: Superintendent of Documents, Uniced States Government Printing Office, 1970.

Skolnick, Jerome, ed. The Politics of Protest: Violent Aspects of Protest and Confrontation. Washington D. C.: Superintendent of Documents, United States Government Printing Office, 1970.

Smith, Donald E. "The Black Revolution and Education." In Banks, James, E. and Jean Grambs, eds., Black Self-Concept. New York: McGraw-Hi11, 1972.

Smith, Kerry. "The Troubled Campus." Current Issues in Higher Education. Washington D.C.: American Association for Higher Education, 1970.

Smith, William. "The Black Studies Graduate in the Real World." Personnel and Guidance Journal. Vol. 48, No. 9 (May, 1970). T67-T69.

Todd, Furniss W. "Black Studies Programs and Civil Rights Violations." A Special Report to the American Council on Education. WashIngton, D.C.:- (1970).

Valentine, Charles. Black Studies and Anthrollology: Scholarly and Political Interests in Afro-American Culture. Redding, Mass.: Addison-Wesiey, 1972 . 
APPENDIX A

QUESTIONNAIRE

Status

School

1. To the best of your knowledge, were there any discussions on campus prior to the formal movement for black studies which paved the way for the introduction of black studies?

2. Do you know if this had made any commitment to help minorities in any way, either on campus, or in the community, prior to the move for biack studies?

3. When did you first become aware that there was a movement afoot for a black studies program on this campus?

(b) How many months before the program was adopted?

(c) Were you informed about biack studies by a student, faculty member, or members of the movement itself, or other?

(d) What were some of the initial responses to the idea of black studies on this campus from the administration, students, and yourself?

4. To the best of your knowledge, who initiated the idea of black studies on this campus?
(1) existing biack faculty
(2) existing white faculty
(3) the administration
(4) Health, Education and Welfare officials
(5) other
(6) coalition of the above

(b) In your opinion, after the group above initiated the idea of black studies, how would you characterize their participation in working toward their goal?
(1) negative participation
(2) moderate
(3) active
(4) very active

5. How did the administration respond to the formal request or demand for black studies, as best as you can remember?
(1) definitely opposed
(2) agreed in principle
(3) were willing to talk further about it (4) started to make plans and set timetables for the completion
of program 
6. How did the students on campus respond to the request or demands for black studies?
(1) definitely opposed
(2) agreed in principle
(3) were willing to talk further
(4) could support demands or requests physically

7. What do you see as the precipitating events on this campus that led to the installation of black studies?
(i) violence: personal vs. pripate
(2) type of agreements
(3) administration's offers vs. students' wants
(4) strategic moves on the part of students and administration

8. Couid you summarize the events in a brief chronological order and tell me when you became involved?
(1) from the beginning
(2) in the middle
(3) toward the end
(4) in the final stage or planning stage of the black studies programs

9. How did you become involved--at whose request: your own, students, faculty, or administration?

10. Did the group or faculty that you represented give you a free hand in representing their interests?
(1) Were your decisions binding on the part of your interest group?
(2) Could you make some decisions without verifications?
(3) Could you make some decisions for your interest group because you knew their position?
(4) Were you part of a team that represented an interest group?
(5) Were you powerless as a decision maker?

11. To the best of your knowiedge, who participated in the actual design of the black studies program?

(b) What was the racial composition of the committee that designed the program?
(1) by race (black and white)
(2) by titie and academic qualifications
(3) faculty (black and white)
(4) students (biack and white)
(5) members of the comunity

(c) Could you tell me as best you can, how long it took to draft the agreement or proposal for black studies? Controversies 
(d) From the time the final draft or agreement was furnished, how long did it take for tion to implement the progiam? :

(the college or institu-

12. How many black students were involved in the beginning in getting biack studies accepted on this campus (to the best of your knowledge?
(1) 1 to 10
(2) 11 to 20
(3) 21 to 30
(4) 31 to 40
(5) 4.1 to 50
(6) 57 to 60

13. How many students, in your opirion, attended classes in black studies or courses related to black studies in the first year of the program's existence?
(1) 1 to 20
(2) 21 to 50
(3) 51 to 700
(4) 101 to 300
(5) 301 to 500
(6) 507 to $\ldots$

14. To the best of your knowledge, has the number of black studies courses increased over the years or have they decreased?

(Explore in terms of student interest, faculty opposition, respondent's personal opinion.)

(Seek measure of interest: high, moderate, active, very active.)

15. What type of commitment or mandate do you feel the administration has made to the black studies on this campus in terms of:

A. additional black faculty and staff:
(1) poor
(2) fair
(3) good
(4) exceilent

B. budgetary concerns:
(1) poor
(2) fair
(3) good
(4) excellent

C. physical space alloted for their duties:
(1) poor
(2) fair
(3) good
(4) excellent

D. channels for the airing of grievences:
(1) poor
(2) fair
(3) good
(4) excellent

16. What type of reception has black studies as a department or academic pursuit received from ocher departments here at

(1) Good college or university.

(3) Poor

(4) Excellent

17. What do you think the contemporary status of black studies at this institution is in terms of its future?
(1) poor
(2) fair
(3) good
(4) excelient

18. What do you think of the acadenic quality of black studies here at (2) poor college or university?
(3) good $\begin{aligned} & 3 \\ & 4\end{aligned}$ excellent 
19. Has black studies, to the best of your knowledge, affected the sentiments, or policies themseives, of this college or university in the areas of:
(1) hiring practices:
(2) the social curriculum of this campus:
(3) changes in controls regarding the conduct of students on campus:
(4) admission policies regarding minorities:

20. How, in your opinion, has the black studies on this campus affected the white student?
(1) poor
(2) good
(3) fair
(4) very well

Have the relationships between the black and white students on this campus been strengthened or weakened as a result of black studies?

(Explore opinion of students that may have confided in respondent.)

21. Of the black students you may know who have left this campus, to the best of your knowledge, has their knowledge of black studies been useful in finding gainful employment?

22. Can you think of anyone else who might be able to provide information about the developmental process of black studies here at (a)
$(b)$
$(c)$
$(d)$
$(e)$
$(f)$
$(g)$ college or university? 
APPENDIX B

\section{EXCERPTS FROM TAPE RECORDINGS}

(Tape recordings of some of the meetings of the Black Studies Council, Portland State University, held during 1969, were made available to the author. The exact dates of the recordings are not always clear. Aithough the voices of some participants have been identified, pseudonymins are used in the following excerpts.)

In the developmental process of $B 1$ ack Studies; there were two types of conflict: (1) overt, where the members of the Black Studies Council met key issues in direct verbal confrontation; and (2) the more subtle conflict which was sustained over long periods of time because key issues were not confronted directly. 
Transcription Number 1: Meeting of the Black Studies Council, Portland State University, Spring, 1969.

The setting: Bob Yates, President of the Portiand State University Student Body, has just read a proposed change in a document submitted to the Council by the Black Student Union. Yates adds a question to his proposed change in the document, and the Chairman of the Council, a white faculty member, responds. Transcription Number One is an example of overt conflict where the issue is directly confronted by both groups.

Chairman: Do you understand clearly that what you have is a tentative draft under consideration by the Black Studies Council?

Yates: I understand that Portland State University is fostering separatism.

Chairman: You're making a false assumption.

Other councit members respond with outrage to the position stated by Mr. Yates; one Council member shouts, "Get out!"

Johnson, a member of the Black Student Union who co-authored the proposed change, then spoke to the Black Studies Council about the reason for the change:

Johnson: The first nine pages of the document we had last week is nothing but an apology for a wrong that has been - - in American history. You did not commit that wrong, and I was not here to let you commit that wrong. I hope our purpose here is to correct that wrong - - and bring forth a program from the black perspective.

Chairman: My objection is not to the substance of what you say here in paragraph three, but the rhetoric.

Johnson: As we've talked before, in department meetings, division meetings, and other meetings, there is always a difference in rhetoric.

Watson: [a white faculty member of the B]ack Studies Counci1] I still don't understand this term "nationalistic."

Other members of the Council murmured their puzzlement also. Then Watson continued:

Watson: Historically, it refers to a nation.

Johnson: A nation of people.

Watson: But a nation is a political unit.

Johnson: Black people are a political factor in this country, as 
White people are. Black people are an economic factor, as white people are. Let's not deny that fact. - - Well, then, would you vant us to say that the black studies program to be meaningful should be a passive program, or a Negro gain program? mean."

Several Council members said, in effect, "That's not what we

Watson: I'm hung up on what we're proposing. If we are proposing a separate black state I would 7 ike to rethink [the whole issue]. This is what the word [nationalistic] has always meant.

At this point several members of the Black Studies Council simultaneously offered definitions and clarifications; the orderly process of the meeting began to break down. 
Black menbers of the Councin never completely trusted the white members to act in the best interests of black students. Part of this mistrust can be seen in the manner in which white faculty members handied issues that were of paramount importance to both the black students and the faculty. A recurrent issue was the qualifications necessary to teach black studies. This issue was continually avoided, and remained unresolved from meeting to meeting.

The following is an example of sustained conflict and mistrust on the part of black members of the council: 
Transcription Number 2: Meeting of the Black Studies Counci7, Port? and State, University, Spring, 1969.

The setting: The council has just met and the Chairman is attempting to clear up business from the previous Black Studies Council meeting.

Chairman: Are there any comments that you'd like to make about the meeting last week, either on the advice given us by $\mathrm{Dr}$. Goodman, or upon the proposal made by Dr. Toml in?

Johnson: I'd like to call the Council's attention to the beautiful piece of, how do you say, reporting in a form, a very unusual form, as dore by the vanguard, and the question That I think was brought up in last week's meeting. And I'd like to know if there was any response from the counci] to the outcome. I think everyone knows what I'm talking about. On: the editorial page referring to the question of "Can a non-biack teach biack studies?"

Chairman: My comment is that though I agree with the premise that [is in] the editorial headlines, I think it over-simplified a fairly complex probiem.

Johnson: And in that you're speaking directly to what?

Chairman: Staffing courses in black studies with black faculty. I don't think it's ever been a real issue. We've all agreed this is the - - . The problem has been and probably will be finding faculty personnel and the dollars to support them; incidentaily, I might say that I am taking steps now to explore the means whereby we can get some faculty F.T.E. for the appointment of a few black professors and I think the prospects $100 \mathrm{k}$ pretty good.

Johnson: I believe I may touch another subject matter that's at hand.

Chairman: No, before we leave this somebody may have some comments on the first question you raised.

Watson: With respect to the editoriai?

Chairman: Yes.

Watson: Well, like most editorials, my own feeling about it, like many editorials, it seiects the gut issues out of a complicated problem and it stated that very nicely. Though if it was intended to be in any sense a reflection of the substance of Professor Coodman's remarks it seems to me that it overlooked the extent to which Goodman himseif was aware of the actual logistical problem that he encountered in Washington. That was my feeling about it. But in 
terms of the basic assumption, I don't think there's any question as far as I can see. 
Hindrances to progress in biack studites can be attributed to the refusal of the facuity to deal with key issues involved in the developmental process of black studies. In the following exchange, the Chairman expresses dissatisfätion with the progress of the Black Studies council and urges the comittee to document its accomplishments to date. The move for documentation implies that: 1) there is a time factor involved; and 2) there is some verbal consensus to previous meetings and positions of the Black Studies Council. However, the latter is not the case in the eyes of the Black Student Union, particularly concerning qualifications to teach black studies. 
Transcription Number 3: Meeting of the Black Studies Council, Portland State University, Spring; 1969.

Setting: After a question of the sincerity of the BTack Studies Councit by Johnson, the Chairman responds:

Chaiman: We11, I'm a little disappointed in the progress we're making. I think we should be a Tittle farther ahead than we are. And again I think that the next step for us to take is to get something down on paper that we can present to the appropriate faculty groups and the Chancellor's office and to the State Board for implementation. I'm going to appear before the Council for Academic Deans Thursday to discuss Black Studies. As I think most of you know, I spent about an hour with the Faculty Senate in January talking about Black Studies and then at this legislative hearing Friday, I'll also talk about Black Studies with the legislators. This doesn't get anything accomplished in the sense that it doesn't represent any sort of formal proposal. But I think the more this topic can be discussed among the faculty, the faculty community, and the community at large, I think the farther we're going to be advanced. We're in a sense preparing the way for faculty consideration when we do have something concrete to [present].

Johnson: I think maybe you and me better sit down and compare notes because I'm going to be taiking with the Senate Thursday and maybe, yeah, I don't want to cross you up because I got the first shot at $i t$. 
APPENDIX C

\section{PROPOSED ETHNIC STUDIES COURSES AT THE \\ UNIVERSITY OF OREGON}

From a memorandum, "Notice of Motion for Consideration at the Faculty Meeting on Wednesday, April 12, 1972," distributed in March, 1972 by the Chaiman of the Ethric Studies Comittee, University of Oregon, pp. 6-9.

\section{COURSES OF STUDY}

The program of study in ethnic studies is grouped into General and Introductory; Culture; History; Sociopolitical; and Human Biological courses. At the moment, not all of the courses listed here qualify equaliy as ethnic studies classes. The content of some of then touches on matters of concern related to ethnic studies rather than dealing directiy with such issues. The expectation of the Ethnic Studies Committee is that the focus of the courses will be sharpened where appropriate so that they all include as much material relevant to ethnic studies as possible.

The Committee aiso foresees the additional necessity to develop series of courses designed specifically to meet the needs of an evolving ethnic studies program. Some such courses will be developed within established departments. Others will have to be established as interdisciplinary courses, perhaps in General Social Science. The Committee feels strongly that an introductory course of this nature should be established for the coming year.

The introductory course should commence with a quarter (or large portion thereof) which introduces the student to the mutti- 
facetel society of modern America, the general social problems and a brief history of its development (a history that examines the separate strains melding into the whole rather than focusing on a sequence of major political events). This introduction should be followed by a quarter in which the course is subdivided into group discussion sections, each taught for students of the various ethnic back-grounds and be individually tailored to treat, for example, politics and social interaction within a particular minority community (e.g., Chicano, Black, Native American, Oriental, White) and the influences upon that community emarating from the larger national society. The individual course must be aimed to produce an understarding on the student's part not only of his or her small segment but of all the segments of that particular minority community, their interaction among themselves and their interaction with the large society (including other minority groups). These courses would, ideally, be taught by instructors who have intimate knowledge of the community about which they teach, either because they grew up in the community and were subsequently trained in disciplines which allow them to integrate the initial experience with later learning, or someone who has been trained in a discipline which emphasizes an uriderstanding of different human, social, political, religious and value systems with as little bias as possible.

The final quarter of the three term sequence should be devoted to an investigation of the current trends and streams of political, social and ciutural events that are shaping our society. Interaction between a11 participants in the course wi1l be strongly encouraged in this quarter to prevent the various factions from isolating them- 
seives in their own world view.

This course must not be viewed as a vehicle of assimilation.

The aim is not to subordinate the minority cultures or absorb them into the national culture, but to aid the minority communities in participating in their own way in the national culture and to understand the various aspects of that national culture.

The course would be 1 isted and described as ES 101, 102, 103"1* ES 101 Ethnic Groups in American Society

ES 102 Ethnic Groups in American Society II

ES 103 Ethnic Groups and the American Experience

The overall course offering in ethnic studies would include at least the following courses:

GENERAL AND INTRODUCTORY:

Eihnic Studies 101, 102, 103 (new courses)

Anth 103 General Anthropology (Cultural) (Principles of Ethnology) Anth 301, 302, 303 Society and Culture (Principles of Ethnology) Geog 105 Urban Environment

Geog 407 Urban Ecology

CSPA 221 Social Issues and Policies: Combatting Racism

CSPA 221 Social Issues and Policies from a Pan-African Perspective CSPA 407 The University Community and Ethnic Group Experience

CULTURE

Anth 417, 418, 419 The American Indian

Anth $426,427,428$ Peoples of Africa

Geog 205 Geography of Africa

Geog 303 The American West

Geog 453 The Cultural Geography of Africa

Geog 463 Geography of Middle America, Mexico, Central America, the Caribbean

Geog 508 Latin American Culture \& Civilization

Mus 407 Introduction to Asian \& African Music

Eng 253, 254, 255 Survey of American Literature (ethnic emphasis)

Eng 310 Introduction to Black Literature

Eng 437 Introduction to Folklore and Mythology

Eng 419 American Folkiore

Eng 407 Major Black Writers

* See pp. 69-70 of this thesis for full course descriptions. 
Rl. 107, 108, 109 Second Year Spanish

RL. 432, 433, 434 Hispanic Culture and Civilization

RL 444, 445, 446 Spanish American Literature

CSPA 407 Mexican-American Culture

HISTORY

Hist 221, 222, 223 Afro-American History

Hist 472 The Negro in American History

Hist 350, 351, 352 Hispanic America

Hist 464 History of Mexico: 1810 to present

SOCIOPOLITICAL

PS 346, 347 Urban Politics

PS 490,491 Community Politics

PS 463, 464 Government and Politics of Latin America

PS 407-507 African Political Literature

PS 407-507 African Policics

Psy 407 Psychology of Prejudice

Psy 437 Social Psychology; Prejudice and Stereotyping

Soc 272 Race, Class \& Echnic Groups in America

Soc 215 Social Issues \& Social Movements

Soc 301 American Society

Soc 305 Contemporary Social Problems

Soc 407 Ghettos, Black \& White

Soc 445 Sociology of Race Relations

CSPA 407 Black American Socialization

HUMAN BIOLOGY

Anth 320 Human Adaptation

Anth 322 Biology of Living Human Populations

Anth 414 Race \& Culture

OTHER COURSES OF RELEVANICE

Econ 474, 475, 416 Regional and Urban Economics

Econ 457, 458, 459 Economic Development

Econ 444 Labor Economics

Econ 4.45 Organized Labor

Econ 446 Labor Legis?ation

Geog 435, 436 Urban Geography

Anth 507 The Negro in the New World

Anth 507 Reservation Indians

Anth 507 Modern Latin America

Anth 507 Medern Mexico

Hist 507 American Negro

Hist 507 Latin American History

Geog 507 The North American City

Hist 476, 477 History of the West

PS 485 Civil Rights \& Civil Liberties 
Psy 438 Social Psychology II

Psy 440 Humen Conflict and Accord

CSPA 407 Counseling of the Disadvantaged

\section{EDUCATION}

CI 340,407 Life Styles of the Poor

CI 347, 407 Alienated-Youth Education

CI 409 Disadvantaged Youth 